\title{
Reconstruction of the unusual Middle Miocene (Badenian) palaeoenvironment of the Carpathian Foredeep (Lomnice/Tišnov denudational relict, Czech Republic)
}

\author{
Katarína HOLCOVÁ ${ }^{1, ~ *, ~ R o s t i s l a v ~ B R Z O B O H A T Y ́ ~}{ }^{2}$, Jitka KOPECKÁ ${ }^{3}$ and Slavomír NEHYBA ${ }^{2}$ \\ 1 Charles University in Prague, Institute of Geology and Paleontology, Faculty of Sciences, 12843 Praha 2, Czech Republic \\ 2 Masaryk University, Departure of Geology and Paleontology, Kotlářská 2, 60000 Brno, Czech Republic \\ 3 Palacký University, Departure of Biology, Faculty of Pedagogy, Hněvotínská 3, 77900 Olomouc, Czech Republic
}

\begin{abstract}
Holcová, K., Brzobohatý, R., Kopecká, J., Nehyba, S., 2015. Reconstruction of the unusual Middle Miocene (Badenian) palaeoenvironment of the Carpathian Foredeep (Lomnice/Tišnov denudational relict, Czech Republic). Geological Quarterly, 59 (4): 654-678, doi: 10.7306/gq.1249

Multiproxy sedimentological, gamma-spectrometric, foraminiferal, calcareous nannoplankton, and otolith data were used for the reconstruction of the Badenian (Middle Miocene) history of the Moravian part of the Carpathian Foredeep. The study material originated from the new borehole LOM-1, which drilled $>20$ metres of monotonous clayey siltstones with exceptionally rich and well-preserved microfossil assemblages. Distal parts of the Carpathian Foredeep (a forebulge depozone) are exposed in this succession. Generally, a quiet environment of outer shelf to upper bathyal of monotonous clayey silts was interpreted, which is typical for the proximal parts of a peripheral foreland basin. The section studied can be subdivided into six intervals, confirming the cyclical character of Middle Miocene sedimentation in the Central Paratethys. Interannual oscillations of nutrient content, temperature and/or salinity are interpreted based on the oscillations of geochemical as well as palaeobiological data. The turnover connected with the initiation of the Middle Miocene Climatic Transition is recorded above the LO (last occurrence) of Helicosphaera waltrans in agreement with previous observations in the Carpathian Foredeep. The changes include cooling, a decrease in nutrients, a probable increase of the salinity of surface water, and increase of seasonality. Seasonality was manifested by an alternation of mixed and stratified water columns with a seasonal input of nutrients. Concerning nutrients, sources of seasonal riverine input or seasonal upwelling are both possible.
\end{abstract}

Key words: Badenian, Carpathian Foredeep, lithology, otoliths, foraminifera, calcareous nannoplankton.

\section{INTRODUCTION}

Isolated relics of Neogene deposits, recognized on the crystalline basement of the Bohemian Massif in western Moravia located beyond the preserved continuous extent of the Carpathian Foredeep Basin (Fig. 1), have been studied by a number of authors (Hladilová et al., 1999; Nehyba and Hladilová, 2004). These relics provided palaeogeographic information about the extent of the basin and are fundamental to the sequence stratigraphic interpretation. Palaeontological studies of some of these relics provide evidence of relatively deep marine conditions (Brzobohatý, 1997; Zágoršek et al., 2009), enough even to suggest that the coast line had to be situated farther inland.

Relics located in the broader surroundings of Tišnov and Lomnice have a specific position due to their exceptionally rich fossil content. Preliminary studies showed minimal taphonomical alteration of microfossil assemblages. Moroever,

\section{* Corresponding author, e-mail: holcova@natur.cuni.cz}

Received: January 21, 2015; accepted: June 25, 2015; first published online: September 16, 2015 the section Borač situated in this area represents a parastratotype of the Badenian substage Moravian (Papp et al., 1978). However, a detailed study of the history of this area has not been made. A newly-drilled borehole (2012) enabled the obtaining of material for detailed multiproxy study of biotic and abiotic evolution in this area during the Middle Miocene. The results of sedimentological, gamma-spectrometric, foraminiferal, calcareous nannoplankton, and otolith analysis are presented in this work.

\section{GEOLOGICAL SETTING}

The Neogene deposits studied represent the sedimentary infill of the Carpathian Foredeep, which formed as a peripheral foreland basin due to the tectonic emplacement and crustal loading of the Carpathian orogen onto the flexed western margin of the Bohemian Massif. Sedimentation in this sector of the basin started in the Egerian/Early Eggenburgian and continued into the Late Badenian (Brzobohatý and Cicha, 1993). The early Middle Miocene (Badenian) forms a distinct stage in the evolution of the basin, when the basin geometry was reorganized by the northward (NW- to NNW-oriented) structural contraction of the Carpathian orogenic wedge (Oszczypko, 1998; Kováč, 2000; Nehyba and Šikula, 2007). 


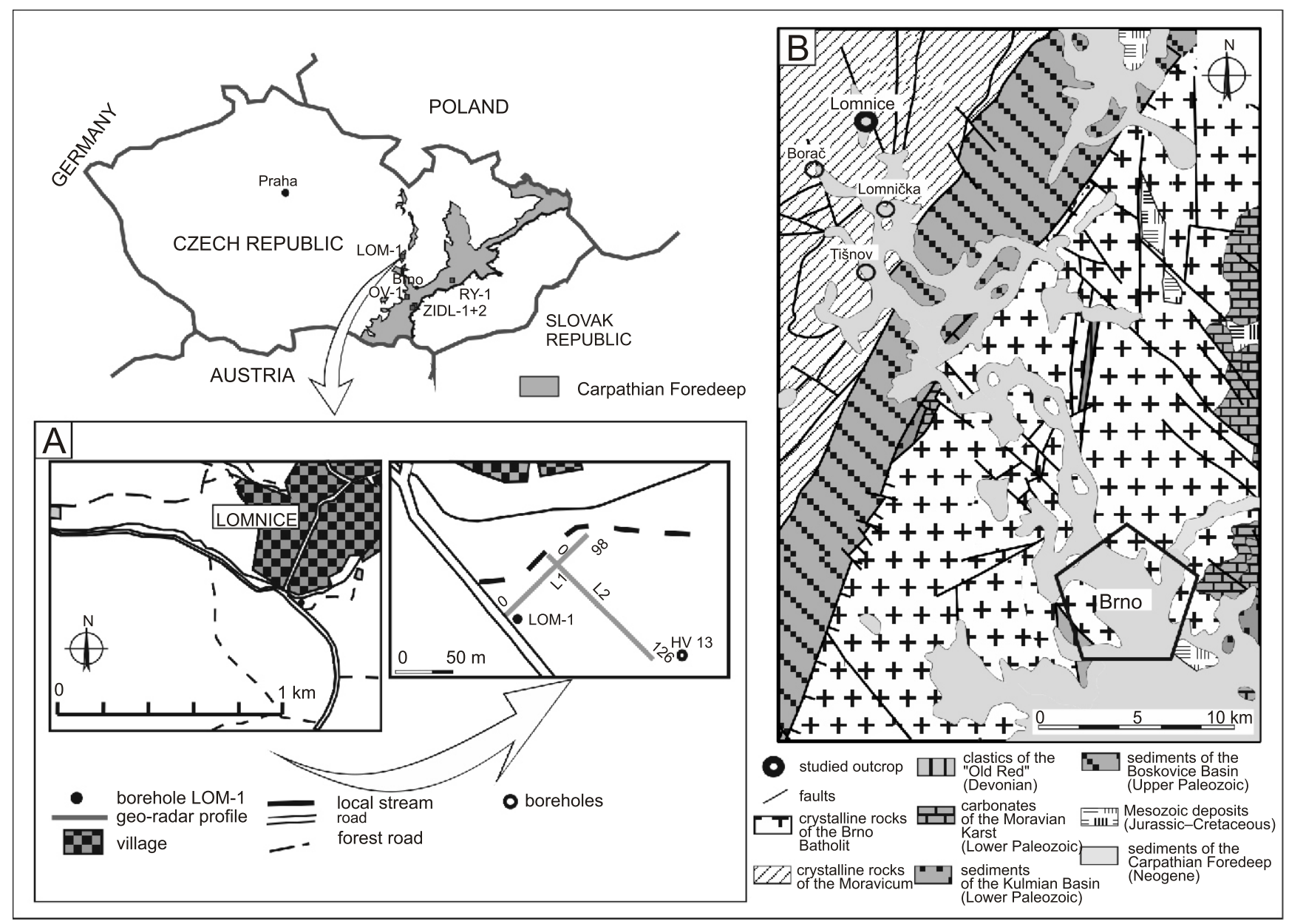

Fig. 1A - geographic location of the Neogene Western Carpathian Foredeep and the LOM-1 borehole studied; B - simplified geological map of the surrounding of the locality

The Miocene deposits in the surroundings of Lomnice are known only as isolated erosional relics. Their exact areal extent is poorly known because of the thick Quaternary cover. These deposits are part of the Carpathian Foredeep, which represents a peripheral foreland basin formed on the loaded eastern margins of the Bohemian Massif due to tectonic emplacement of the Carpathian thrust wedge. Sedimentation in this western sector of the Carpathian Foredeep commenced in the Egerian to Early Eggenburgian, and continued into the Late Badenian. In the early Middle Miocene, the basin geometry was reorganized by the northward (NW- to NNW-oriented) structural contraction of the Carpathian orogenic wedge, and so the Badenian deposits of the foreland basin represent a distinct period of the basin evolution (Nehyba and Šikula, 2007).

Miocene deposits at Lomnice are represented by calcareous clays, sandy clays, quartzose sands, calcareous sands, and algal limestones (Hudec, 1986), and they lie on the Pre-Neogene basement formed by the metamorphic rocks of the Svratka unit of the Moravian Zone (Precambrian) (Mísař et al., 1983). Pluskal (1853) wrote probably the first reports on Miocene deposits in the broader surroundings of Tišnov (i.e. the localities of Borač, Lomnička, Tišnov a Lomnice). Procházka (1892a, b, 1893, 1899) published extended palaeontological and stratigraphical studies of these localities. $\mathrm{He}$ interpreted the deposits as marine ones, deposited along a very irregular coastline with numerous bays and islands, with an important role played by basement relief. Novák (1975) and
Zdražílková (1985) studied the Lower Badenian limestones in the area and speculated on their deposition in a narrow sea bay with an important input of terrigenous material. Brzobohatý (1975) - based on the study of otoliths - interpreted normal salinity conditions and deposition in the shallower neritic (infralittoral) environment. Hladil (1976) studied Scleractinia from the locality. Hamršmíd (1985) described the trace fossil Helicotaphrichnus commensalis from the Lomnice locality.

The stratigraphic position of these deposits is based mainly on the study of gastropoda and corals. The Lower Badenian age of these deposits is confirmed by occurrences of Turritella spirata, Nassa restitutiana, Mitra scrobiculata and Anachis moravica (e.g., Hudec, 1986).

To obtain quantitative data for detailed biostratigraphical and palaeoenvironmental analysis, a cored shallow borehole was recently drilled near the town of Lomnice (Fig. 1A), and is referred to as borehole LOM-1 (GPS location $49^{\circ} 23.945^{\prime} \mathrm{N}$ and $016^{\circ} 24.542$ 'E, $382 \mathrm{~m}$ a.s.I.). A simplified geological map of the broader surroundings of the locality is shown in Figure 1B.

\section{MATERIAL AND METHODS}

The Badenian history of the Lomnice denudation relict, situated in the Moravian part of the Carpathian Foredeep, was studied using material originating from the new borehole LOM-1, which drilled $>20$ metres of monotonous clayey 
siltstones. Detailed lithofacies and biofacies analysis based on multiproxy sedimentological, gamma-spectrometric, foraminiferal, calcareous nannoplankton, and otholith data was carried out with the aim of biostratigraphy, facies, and palaeoenvironment interpretation as well as for correlation with other Central Paratethys basins.

Lithofacies analysis is based on the study of sedimentary textures and structures following Walker and James (1992), Tucker (1995), and Nemec (2005). The technique of laser diffraction (Cilas 1064 granulometer) was used for grain-size analysis (35 analyses). Ultrasonic dispersion, distilled water, and washing in sodium polyphosphate were applied prior to analyses in order to avoid flocculation of the particles analysed. The gamma-ray spectra (GRS) were measured by a GR-320 enviSPEC laboratory spectrometer with a $3 \times 3$ in. $\mathrm{Nal}(\mathrm{TI})$ scintillation detector (Exploranium, Canada). Counts per seconds in selected energy windows were directly converted to concentrations of $\mathrm{K}(\%), \mathrm{U}(\mathrm{ppm})$, and Th (ppm). One measurement with a 30 min. count time was performed for each sample measured (60 samples - min. $300 \mathrm{~g}$ in weight).

Ground-penetrating radar (GPR) scanning employed a Pulse Ekko Pro radar, manufactured by the Canadian company Sensor \& Software, at a frequency of $50 \mathrm{MHz}$ with an antenna distance of $3 \mathrm{~m}$. The measurement interval was $0.5 \mathrm{~m}$. Processing of the data was done by Kolejkonzult Brno co.

Foraminifera were studied from 62 samples (Fig. 2), from 63-2000 $\mu \mathrm{m}$ fractions. About 200-300 specimens of foraminifera from each sample were quantitatively evaluated. Postmortem changes of assemblages were evaluated using the criteria of Holcová (1999).

Calcareous nannoplankton were studied from 80 samples, 62 of them identical to the foraminifera samples. The abundance of nannoplankton was expressed semiquantitatively as the number of specimens in the visual field of the microscope. The following categories were distinguished: (1) very rare: 1-2 specimens, (2) rare: $3-5$ specimens, (3) common: 6-10 specimens, (4) abundant: 11-20 specimens, (5) very abundant: 21-40 specimens, (6) mass occurrence: $>40$ specimens. About 200-500 specimens of calcareous nannoplankton were determined from individual samples and the relative abundances of taxa were calculated. The abundances of diatoms in the calcareous nannoplankton slides were recorded using a simple semi-quantitatively scale: (1) very rare: 1 specimen in visual field of microscope; (2) rare: 2-3 specimens; (3) common: 3-5 specimens; (4) abundant: $>5$ specimens.

Benthic and planktonic foraminiferal assemblages, as well as calcareous nannoplankton, were statistically classified using the non-Metric Multidimensional Scaling technique (nMMDS) of the Paleontological Statistic (PAST) software (Hammer et al., 2001): the method was used for the classification of samples. Differences in assemblage composition were tested by the Kruskal-Wallis test.

Otolith associations were obtained by screenwashing all remaining material of the borehole using a $0.4 \mathrm{~mm}$ mesh. Otoliths were studied from 22 samples (taken each metre of the whole section). The systematic and quantitative distribution of taxa in samples are given in the Appendices $1-4^{*}$. Every sample has

Fig. 2. Sedimentological core logs of the LOM-1 borehole and sampled intervals

\footnotetext{
* Supplementary data associated with this article can be found, in
} the online version, at doi: $10.7306 / g q .1249$

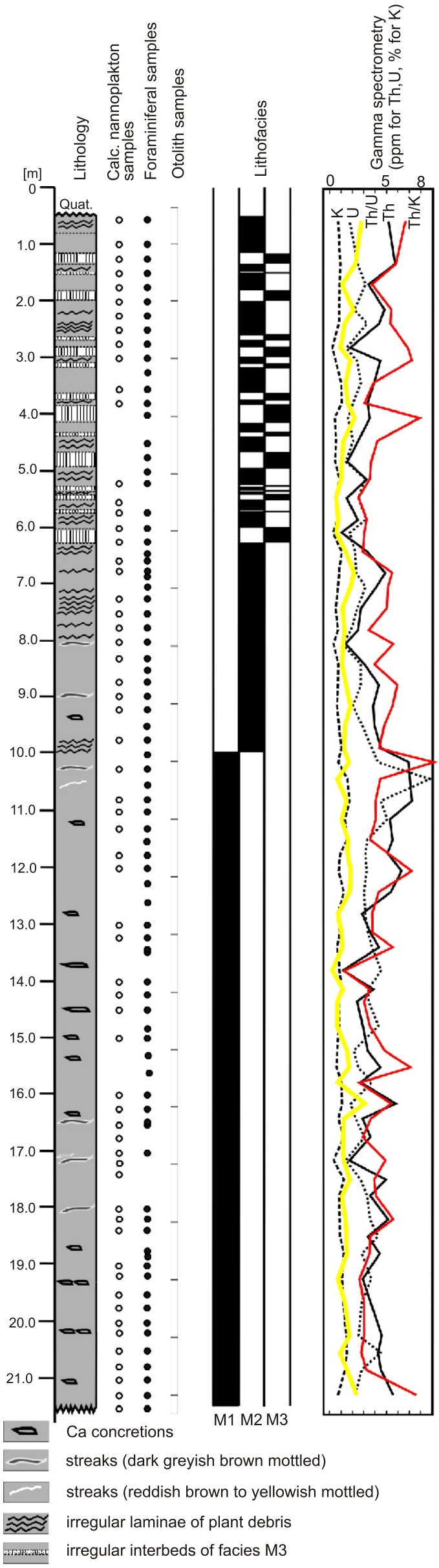



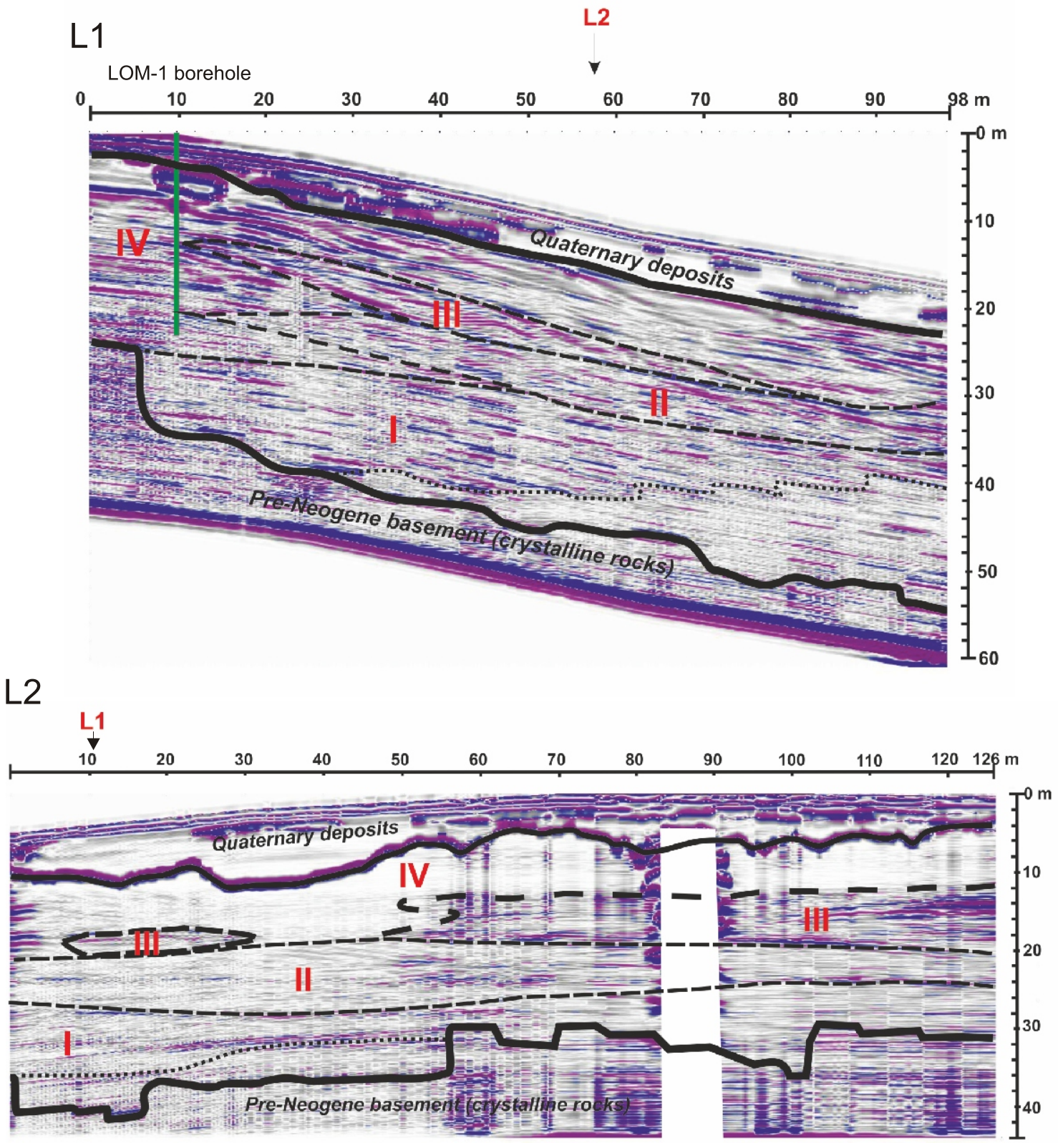

Fig. 3. Ground-penetrating radar profiles near to the LOM-1 borehole

For location see Figure 1

been analysed by using the palaeobathymetric method proposed for otoliths by Nolf and Brzobohatý (1994). Some representative graphs are shown.

\section{RESULTS}

\section{GEO-RADAR SURVEY}

Two geo-radar profiles were measured at the locality with the aim of determining the relief of the underlying pre-Neogene bedrock and to better understand the depositional architecture of the Lower Badenian deposits. Geo-radar profiles were calibrated by the results of the new boreholes LOM-1 and HV 13 (Jahoda, 1988). The location of the profiles is illustrated in Figure 1.
Interpretation of the geophysical profile at Lomnice indicates (Fig. 3), that the Early Badenian deposits rest on a highly irregular surface of pre-Neogene bedrock formed by the metamorphic rocks of the Svratka unit, which is generally inclined towards the NE-NNE. The thickness of the Lower Badenian deposits ranges from 10 to about $30 \mathrm{~m}$. The thickness of the Quaternary sediment cover varies between 1 and $4 \mathrm{~m}$. Four lithological units can be identified in the Neogene deposits studied and their lithological content can be deduced after calibration using the LOM 1 and HV 13 boreholes and the results of Hudec (1986). Arrangement of recognized Neogene lithological units is partly planar ("aggradational") but mostly inclined ("accretional") generally towards the NE. The topmost unit I, which is also penetrated by borehole LOM-1, has an irregular wedge shape, its thickness is generally reduced towards the 
NE. The lowermost unit I covers the pre-Neogene basement and its shape and thickness strongly varies due to irregular basement relief. Deposits of unit I are maximally $12 \mathrm{~m}$ thick (mostly only a few $\mathrm{m}$ ) and they are most probably formed by sands and gravelly sands. The next unit II reveals a tabular to broadly lensoidal shape and covers unit I in the NE part of the area studied. Uunit II interfingers partly with unit IV (in the SW part of the area studied) but also represents the subsurface of unit III (towards the NW). The maximum thickness of unit II is $6 \mathrm{~m}$ and its deposits are mostly sands. Unit III has a very irregular lensoidal shape, a discontinuous extent and is maximally $4 \mathrm{~m}$ thick. This unit is probably formed by sandy limestones or calcareous sandstones. Such limestones were widely documented in the adjacent area and can be found also within the soil on the surface (Novák, 1975; Zdražílková, 1985; Doláková et al., 2008). Unit III mostly rests on unit II. The topmost unit IV has a tabular to wedge shape. Its thickness reaches over $20 \mathrm{~m}$ in the SW part of the area studied, where it directly overlies unit I. The sedimentary infill of unit I is documented by LOM-1 and is formed by clays and silts.

\section{SEDIMENTOLOGICAL AND GAMMA-RAY SPECTRAL ANALYSES}

Three sedimentary facies were recognized in the borehole. Descriptions of the lithofacies are shown in Table 1. The dominant lithofacies M1, which was recognized in the lower part of the borehole, is represented by green-brown, olive-green and rarely dark grey clayey silt, in places irregularly dark greyish brown mottled. Lithofacies M2 was described in the middle and upper parts of the succession. It is formed by light grey-green to grey-brown, calcareous clayey silt to clayey silt, locally reddish brown or yellowish mottled. Lithofacies M3 was identified only in the upper part of the succession and is formed by whitish clayey silt. Deposits of all facies are calcareous and structureless. The distribution of individual facies in the borehole profile can be seen in the lithostratigraphic log (Fig. 2).

The clayey silts of facies M1 reveal positive correlations between contents of $\mathrm{K}$ and Th (linear regression coefficient $R=$ $0.48), \mathrm{K}$ and $\mathrm{U}(R=0.44)$ and also $\mathrm{Th}$ and $\mathrm{U}(R=0.33)$. Low positive correlations can be seen between $\mathrm{K}(R=0.20)$, Th $(R=$ $0.11), \cup(R=0.23)$ and clay content. But low negative correla- tion was on the other hand recognized for $\mathrm{K}(R=-0.21)$, Th $(R=$ $-0.19), \cup(R=-0.28)$ and silt content.

The superimposed deposits of facies $\mathrm{M} 2$ reveal good positive correlations recognized between $\mathrm{K}$ and Th $(R=0.57), \mathrm{K}$ and $U(R=0.54)$ and only slightly lower for Th and $U(R=0.35)$. Also relatively high positive correlations can be seen between $\mathrm{K}$ $(R=0.64)$, Th $(R=0.45), \cup(R=0.51)$ and clay content. On the other hand significant negative correlation was recognized for $\mathrm{K}$ $(R=-0.65)$, Th $(R=-0.47), \cup(R=-0.53)$ and silt content.

The clayey silts of facies M3 have ood positive correlations recognized between $\mathrm{K}$ and Th $(R=0.82), \mathrm{K}$ and $\mathrm{U}(R=0.69)$ and only slightly lower for Th and $U(R=0.31)$.

Despite the general grain size uniformity of the samples the spectral gamma-ray logs show a considerable degree of vertical variation (Fig. 2).

BIOTA

Calcareous nannoplankton. Calcareous nannoplankton (Figs. 4, 5 and Appendix 1) are well-preserved; their abundances oscillate from common to mass occurrences. Above the level of the LO of Helicosphaera waltrans $(0.6-5 \mathrm{~m})$ calcareous nannoplankton abundance show a decrease. The species Reticulofenestra minuta dominates in most assemblages, and in the vast majority of samples reaches an abundance of $>50 \%$ with the exception of interval 10.25-10.75 m (Fig. 5D) where the small $R$. minuta is substituted by larger $R$. haqii. Abundances of Coccolithus pelagicus are around $10 \%$ in the interval from 9.75 to $16.0 \mathrm{~m}$ with occasional peaks reaching $30 \%$. Below $19.5 \mathrm{~m}$ and mainly above $8.3 \mathrm{~m}$, the abundances of $C$. pelagicus decrease; they are $<10 \%$. Umbilicosphaera jafari appears randomly from the base to $8.3 \mathrm{~m}$ where the continuous occurrence started. Abundances of last common group Helicosphaera spp. vary from 0 to $15 \%$ in three cycles with minimal occurrences at the base of borehole and at levels of 16.5 and $6.6 \mathrm{~m}$ (Fig. 5). Results of nMMDS enable five intervals to be defined as shown in Figure $5 \mathrm{H}$.

Planktonic foraminifera. Planktonic foraminifera (Fig. 6J-O, R, S, V, AF-AH, AM, AN, Fig. 7 and Appendix 2) are well preserved without marked signs of transport (size-sorting, abrasion or breakage). The P/B-ratio (percentage of planktonic

Description of the lithofacies recognized in the cores of borehole LOM-1

\begin{tabular}{|c|c|}
\hline $\begin{array}{l}\text { Facies } \\
\text { symbol }\end{array}$ & Description \\
\hline M1 & 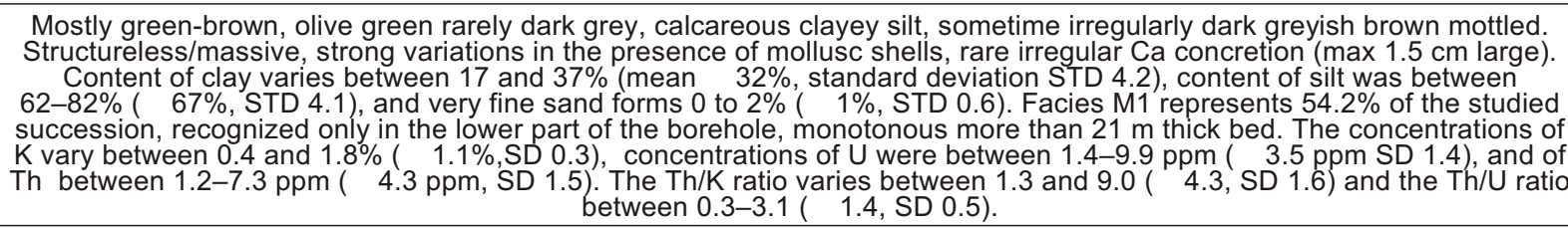 \\
\hline M2 & 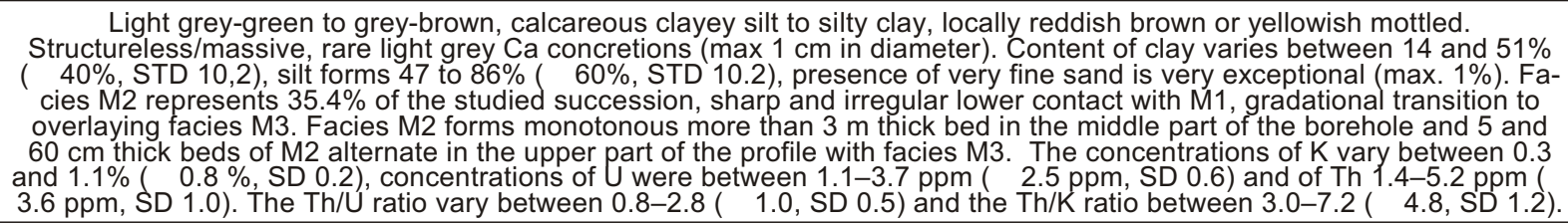 \\
\hline M3 & $\begin{array}{l}\text { Whitish, calcareous clayey silt, structureless/massive. Content of clay varies between } 29 \text { and } 33 \% \text { and silt forms } 67 \text { to } 71 \% \text {, } \\
\text { sand was not recognized. Facies M3 represents } 10.4 \% \text { of the studied succession, forms irregular beds with maximum thick- } \\
\text { ness of } 35 \mathrm{~cm} \text {, recognized only in the upper part of the succession, where it alternates with facies M2. The concentrations } \\
\text { of K vary between } 0.3 \text { and } 1.0 \%(\varnothing 0.6 \% \text {, SD } 0.2) \text {, concentrations of U were between } 1.5-2.6 \mathrm{ppm}(\varnothing 2.0 \mathrm{ppm}, \mathrm{SD} 0.5) \text { and } \\
\text { of Th } 1.1-5.7 \mathrm{ppm}(\varnothing 2.7 \mathrm{ppm} \mathrm{SD} 1.7) \text {. The Th/U ratio vary between } 0.6-2.3(\varnothing 1.4, \mathrm{SD} 0.8) \text { and the Th/K ratio between } \\
2.6-7.9(\varnothing 4.6, \mathrm{SD} 2.0) \text {. }\end{array}$ \\
\hline
\end{tabular}


foraminifera in the total foraminiferal assemblage) varies from $20-80 \%$ but most of the values fall within the interval $30-50 \%$ with peaks at 18-18.4 m, $12 \mathrm{~m}, 9-11 \mathrm{~m}$ (Fig. 7B). Globigerina praebulloides, G. bulloides, Turborotalita quinqueloba and warm-water species (Globigerinoides spp., Globigerinella spp.) dominate in assemblages, and their contributions fluctuate. A marked peak of warm-water species was recorded at levels of $18.4 \mathrm{~m}$ followed by gradual decrease to the level $11.3 \mathrm{~m}$. A further significant peak of warm-water species characterizes the interval 9.7-11 $\mathrm{m}$ and the last peak was recorded at level $2.5 \mathrm{~m}$ (Fig. 7F). Relative abundances of Turborotalita quinqueloba are low in intervals from 14 to $21.5 \mathrm{~m}$ and vary between $0-10 \%$, then increase $(5-25 \%)$ and at the level of $5.6 \mathrm{~m}$ the species nearly disappears (Fig. 7E). Globigerina bulloides is common; its abundance oscillates between $30-40 \%$, and is approximately the same. Globorotaliids are rare (to $10 \%$, very rarely to $20 \%$ ) with an increase in the upper part of the sections (above $3.8 \mathrm{~m}$ ). Results of nMMDS enable seven intervals to be defined as shown in Figure 7 I.

Benthic foraminifera. Similarly to planktonic foraminifera, benthic foraminifera show no signs of transportation (Fig. 6A-I, P, Q, T, U, W-AE, Al-AL, Fig. 8 and Appendix 3). The diversity of benthic foraminifera assemblages was expressed simply as the number of species in individual samples: those diversities vary around 20 (16-24 species/sample) which is generally low (Fig. 8B). At levels 15, 12, 11.3 and 9.5-8.75 m numbers of species drop even to $<10(11.3,9-9.2 \mathrm{~m})$. The base of the borehole can be characterized by a dominance of Bulimina spp. and high diversity of assemblages. Oscillations in relative abundances of hypoxic taxa (Uvigerina spp., Bulimina spp., Praeglobobulimina spp. and Bolivina spp.), lagenids and high-nutrient markers (Melonis spp. and Pullenia spp.) and a decrease in diversity were recorded in the next interval $(12-20 \mathrm{~m})$ with peaks of hypoxic taxa at levels 19.2, 16, 14.5 and $14 \mathrm{~m}$. Diversity decrease at $18.4 \mathrm{~m}$ can be correlated with a peak of high-nutrient markers. High relative abundances of lagenids and agglutinated foraminifera were recorded in the interval 8.7-12 $\mathrm{m}$ and can be correlated with a diversity decrease. In particular, a peak of lagenids at $12 \mathrm{~m}$ accompanied by the disappearance of hypoxic taxa is notable. A clear peak of Gyroidina spp. characterizes the interval from 10.75 to $9.5 \mathrm{~m}$ (Fig. 8I). Around $8 \mathrm{~m}$ abundances of hypoxic taxa increase, Uvigerina spp. re-appear and diversity begins to increase. The last marked change was recorded at level $3.6 \mathrm{~m}$ where abundances of Cibicidoides spp. increase while lagenids decrease and diversity starts to be high. This trend continues into the highest parts of the sections, where Sphaeroidina spp. appears and relative abundances of shallow-water taxa (Elphidium spp., miliolids, Asterigerinata planorbis) reach values of around $5 \%$ at the top of section. Results of nMMDS enable eight intervals to be defined as shown in Figure $8 \mathrm{~J}$.

Otoliths. The profile studied yielded 40 taxa, 24 of them as nominal species and 10 of them still extant (Fig. 9 and Appendix 4). The frequency histograms show the nearly identical distribution throughout the whole section (Fig. 10). Strongly dominant are myctophids (mostly Diaphus, $\sim 10$ species, representing nearly always $>90 \%$ of all otoliths) in all intervals. The other meso- and bathypelagic taxa such as Sternoptychidae (first of all Maurolicus muelleri and less frequently Valenciennellus tripunctulatus) and Vinciguerria poweriae occur in smaller numbers. This overall picture is complemented by sporadic and first of all juvenile otoliths of deep sea-dwelling macrourids (Coelorincus, Gadomus, Nezumia), other demersal fishes tending to the deep-water (Polyipnus, Merluccius, Hoplostethus, Physiculus huloti) and the relatively abundant pelagic Gadiculus argenteus argenteus. The assemblage con- tains the first Miocene record of the present-day meso- and bathypelagic fish species Bonapartia pedaliota (see Fig. 9A) currently known also from the Mediterranean Pleistocene (Girone and Varola, 2001).

Otoliths of fishes living in a neritic environment (e.g., gobiids, Atherina, Lithognathus) occur very sporadically and are represented by juvenile or often corroded specimens dispersed irregularly throughout the whole section. Only small and broken clupeids occur in small numbers (1-4 specimens) in samples between 10-17 $\mathrm{m}$. Despite the presence of deep-sea living fishes, subtropical taxa predominate. The genus Brachydeuterus living today in tropical seas is represented only by otoliths of the fossil species $B$. speronatus in the interval 13-14 $\mathrm{m}$. This species could have had a slightly broader climatic tolerance than the present-day species $B$. auritus (see Brzobohatý et al., 2007). On the other hand the pelagic Gadiculus argenteus argenteus, living mostly in moderate seas today, is present through the whole section, sometimes occurring in relatively great numbers (e.g., interval 6-7 m). This could also be supported by the sporadic occurrence of juvenile otoliths Merluccius merluccius. But other psychrophile gadoids known from the same stratigraphic level from the northernmost Central Paratethys (Trisopterus, Micromesistius; Poland, Radwańska, 1992), or from the younger uppermost Badenian deposits of the Vienna Basin (Brzobohatý et al., 2007) are not present.

As for the salinity, purely marine taxa predominate. Only very sporadic otoliths representing euryhaline taxa are dispersed irregularly throughout the whole section (Atherinidae, Gobiidae). No typical brackish or freshwater taxa were found.

The palaeobathymetric analyses document relatively stable conditions at interval 1-19 m (except 4-5 m, where the number of taxa is small) and indicate sedimentation depths between 200-300 m (e.g., Fig. 11 for sample from the 18-19 m interval). Somewhat deeper conditions could be represented by the base of the borehole (19-22 m, Fig. 12D) where only two juvenile otoliths of neritic fish are present. In contrast, the top of the section ( $0-1 \mathrm{~m})$ documents marked shallowing indicating by the occurrence of 4 neritic taxa and a lower number of myctophid otoliths (Figs. 10A and 12D).

\section{COMPARISON OF THE LOM-1 SECTION WITH OTHER MIDDLE MIOCENE CARPATHIAN FOREDEEP SECTIONS}

Foraminiferal and calcareous nanoplankton assemblages were compared with isochronous sections of the NN5 calcareous nannoplankton zone from the Moravian part of the Carpathian Foredeep: boreholes Židlochovice (ZIDL-1+2; Doláková et al., 2014), Rybníček (RY-1; foraminifera Kopecká, 2012; calcareous nannoplankton - Holcová, unpubl. data) and Oslavany (OV-1; Nehyba et al., in press; Fig. 1A). Results of nMMDS (Fig. 13A) as well as comparison of assemblage composition (Fig. 14) showed the following differences: (1) calcareous nannoplankton of the LOM-1 section are near to nannoplankton from the ZIDL-1+2 sections in the high abundances of Reticulofenestra minuta and low abundances of larger $R$. haqii. Slightly lower abundances of Coccolithus pelagicus and higher abundances of Umbilicosphaera jafari characterize the LOM-1 and OV-1 sections which also overlapped in the nMMDS plot (Fig. 10A). Higher abundances of large Helicosphaera spp. (excluding small $H$. walbersdorfensis) distinguish the LOM-1 section from other ones compared. (2) Planktonic foraminiferal assemblages showed only narrow variability and slightly overlapped with the OV-1 and very slightly 

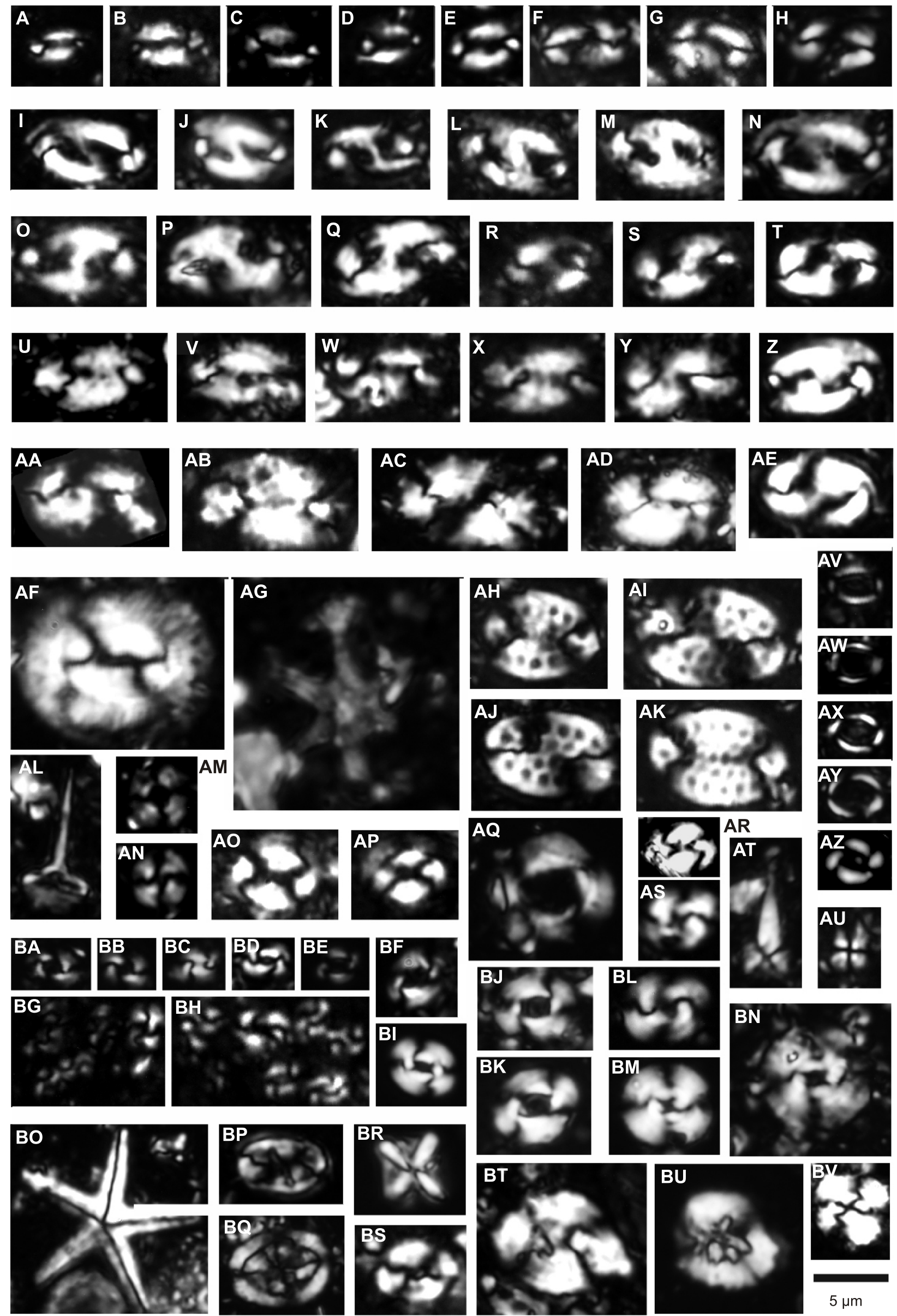
with the ZIDL-1+2 sections while the RY-1 section markedly differs (Fig. 13B). High abundances of 4-chambered Globigerina bulloides, G. praebulloides and Globigerinella regularis and low abundance of Paragloborotalia spp. characterize only the LOM-1 section. Turborotalita quinqueloba is quite rare. Similarly to the OV-1 section low abundances (but slightly higher than in the ZIDL-1+2 boreholes) of Globigerinoides spp. and Globorotalia bykovae were recorded. (3) Benthic foraminifera from the LOM-1 section differ from other sections mainly by high abundances of the genera Melonis, Pullenia and Nonion commune. Similarly to the case at Rybniček, Ammonia spp., Elphidium spp., miliolids and Cassidulina spp. are nearly absent while Uvigerina spp. are abundant. As in the OV-1 section, abundances of agglutinated taxa as well as Cibicidoides spp. are lower, and Bolivina spp. are higher as in other compared sections (Figs. 13C and 14).

Otolith assemblages in the southern part of the Carpatian Foredeep were divided into 4 palaeobathymetric groups (Brzobohatý, 1997). The entire section LOM-1 belongs to the second deepest assemblages documented at the localities Lomnice (120 m NW from the LOM-1 Borehole), Lomnička u T., Voděrady, Černá Hora and Drnovice (the middle part of the Carpathian Foredeep in Moravia). They are characterized by the dominance of diaphids, the number of macrourids and stomiiforms and the frequent occurrence of Gadiculus argenteus argenteus otoliths. All named sections represent depths lying between palaeoisobaths 200-300 m, as constructed for the Badenian Sea in the South Moravian part of the Carpathian Foredeep by Brzobohatý (2001). The upper sections of the boreholes Židlochovice (ZIDL-1+2) discussed suggest bathymetrically shallower conditions, while at Rybníček (RY-1) deeper conditions (Brzobohatý, 1997, 2001; Doláková et al., 2014).

\section{INTERPRETATION AND DISCUSSION}

FACIES ANALYSIS

The monotonous succession of mostly structureless silty clays and clayey silts of facies M1, M2 and M3, the paucity of sand and of any coarse extraclasts, together with good preservation of calcarous shells, all point to deposition in a quiet offshore setting with no input of coarse bedload material or wave action. The lack of stratification, and dispersion of silt and very fine sand within the clay suggest deposition from a dense fluid mud following deceleration of flow. The matrix strength of the fluid mud was apparently sufficient to support suspended silt grains (Plint, 2014). The significant thickness of these monotonous deposits could point to a balance between sediment input and the formation of accommodation space. We can speculate about relative rapid sediment delivery, relative rapid sea-level rise and deposition in a sheltered bay/estuary (?) taking into account possible basin palaeogeography. The differences between selected lithofacies reflect probably variations in the type and intensity of weathering (i.e., processes in the source area), but not significant differences in depositional processes.

The dominant source of the gamma signal is carried by the clay fraction. The low concentrations of $K$ and the value of $T h / K$ ratio could be a signal of the presence of kaolinite in the clay fraction instead of illite, and the prevalence of humid conditions in the source area (Rider, 1999). The generally low concentrations of studied elements (especially of $\mathrm{K}$ ) point to deeply weathered source rocks (in comparison with the basement formed by metamorphic rocks of the Svratka unit). However, the relative low stability of the $\mathrm{Th} / \mathrm{K}$ value and vertical variation in the content of $\mathrm{K}$ and $\mathrm{Th}$, reflect variations in the delivery and character of clastic material, which may be connected with several factors (e.g., climate, relative sea level change, dysoxic vs. anoxic conditions). Moreover, the gamma signal is usually sourced in the wider mineral spectra.

\section{BIOSTRATIGRAPHY}

The biostratigraphic correlation of the section is based on the first and last occurrences of planktonic foraminifera and calcareous nannoplankton index species (Gradstein et al., 2012). Our succession of bioevents matches well the successions in the Mediterranean area (Abdul Aziz et al., 2008; Di Stefano et al., 2008; Hüsing et al., 2010), where the LO (Last Occurrence) of Praeorbulina spp. is an indefinable event which may be observed above the LO of Helicosphaera waltrans. The same succession of bioevents was described in the Carpathian Foredeep by Švábenická (2002) and also in the borehole RY-1 Rybníček (Kopecká, 2012) and OV-1 Oslavany (Nehyba et al., submitted). The succession of bioevents is summarized in Figure 15.

From the index species, Praeorbulina (LO 14.9 Ma: Gradstein et al., 2012; Mediterranean area: Abdul Aziz et al.,

\section{Fig. 4. Calcareous nannoplankton from the LOM-1 borehole}

A-H - Helicosphaera walbersdorfensis Müller, 1974: A, B - 1.5 m, C, D - 2.25 m, E - 5.6 m, F - 8.75 m, G - 9.2 m, H - 10.25 m; I-T, Z, AE Helicosphaera waltrans Theodoridis, 1984: I-K - 21.3 m, L-O - 19.25 m, P, Q - 19.0 m, R - 18.2 m, S, T - 16.5 m, Z - 20.7 m, AE - 20.2 m; U-Y, AA-AD - Helicopshaera carteri (Wallich, 1877) Kamptner, 1954: U-X - 9.0 m, Y - 10.25 m; AA - 1.25 m, AB, AC - 19.0 m, AD - 20.0 m; AF - Coccolithus miopelagicus Bukry, 1971, 19.25 m; AG - Discoaster variabilis Martini and Bramlette, 1963 , 14.0 m; AH-AK Pontosphaera multipora (Kamptner, 1948 ex Deflandre, 1954) Roth, 1970: AH - 10.5 m, Al, AJ - 10.75 m, AK - 16.5 m; AL - Rhabdosphaera sp., 18.0 m (reworked Paleogene); AM, AN - Umbilicopshaera jafari Müller, 1974, 0.6 m; AO, AP - Coccolithus pelagicus (Wallich, 1877) Schiller, 1930: AO - 21.0 m, AP - 1.0 m; AQ - Reticulofenestra pseudoumbilicus (Gartner, 1967) Gartner, 1969- large, clearly separated from R. minuta-haqii group, 16.25 m; AR - Reticulofenestra scrippsae (Bukry et Percival, 1971) Roth, 1973, 14.25 m (Oligocene-lowermost Miocene); AS, BL-BN - Cyclicargolithus floridanus (Roth et Hay in Hay et al., 1967) Bukry, 1971: AS - 8.5 m, BL - 10.25 m, BM, BN 16.5 m; AT, AU - Sphenolithus heteromorphus Deflandre, 1953; 1.75 m; AV-AZ - Syracopshaera pulchra Lohmann, 1902 : AV - 2.5 m, AW -

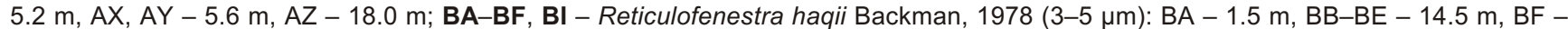
$16.45 \mathrm{~m}, \mathrm{BI}-16.5 \mathrm{~m}$; BG, BH - Reticulofenestra minuta-R. haqii plexus (diameters of figured specimens $2-4 \mu \mathrm{m}$ ): $\mathrm{BG}-14.5 \mathrm{~m}, \mathrm{BH}-9.5 \mathrm{~m}$; BJ, BK - Reticulofenestra pseudoumbilica (Gartner, 1967) Gartner, 1969 - small, continuous transition to R. minuta-R. haqii group, 2.75 m; BO - Micrantholithus vesper Deflandre, 1950, 2.25 m; BP - Eifelithus sp., 11.6 m (reworked); BQ - Archangelskiella sp., 17.0 m (reworked Cretaceous); BR - Micula sp., 20.2 m (reworked - Cretaceous); BS, BT, BV - Watzenauria spp.: BS - 2.25 m, BT - 18.2 m, BV - 21.5 m (reworked - Mesosoic); BU - Lotharingus sp., 2.25 m (reworked - Mesosoic). Deposition of material: Department of Geology and Paleontology, Charles University in Prague 


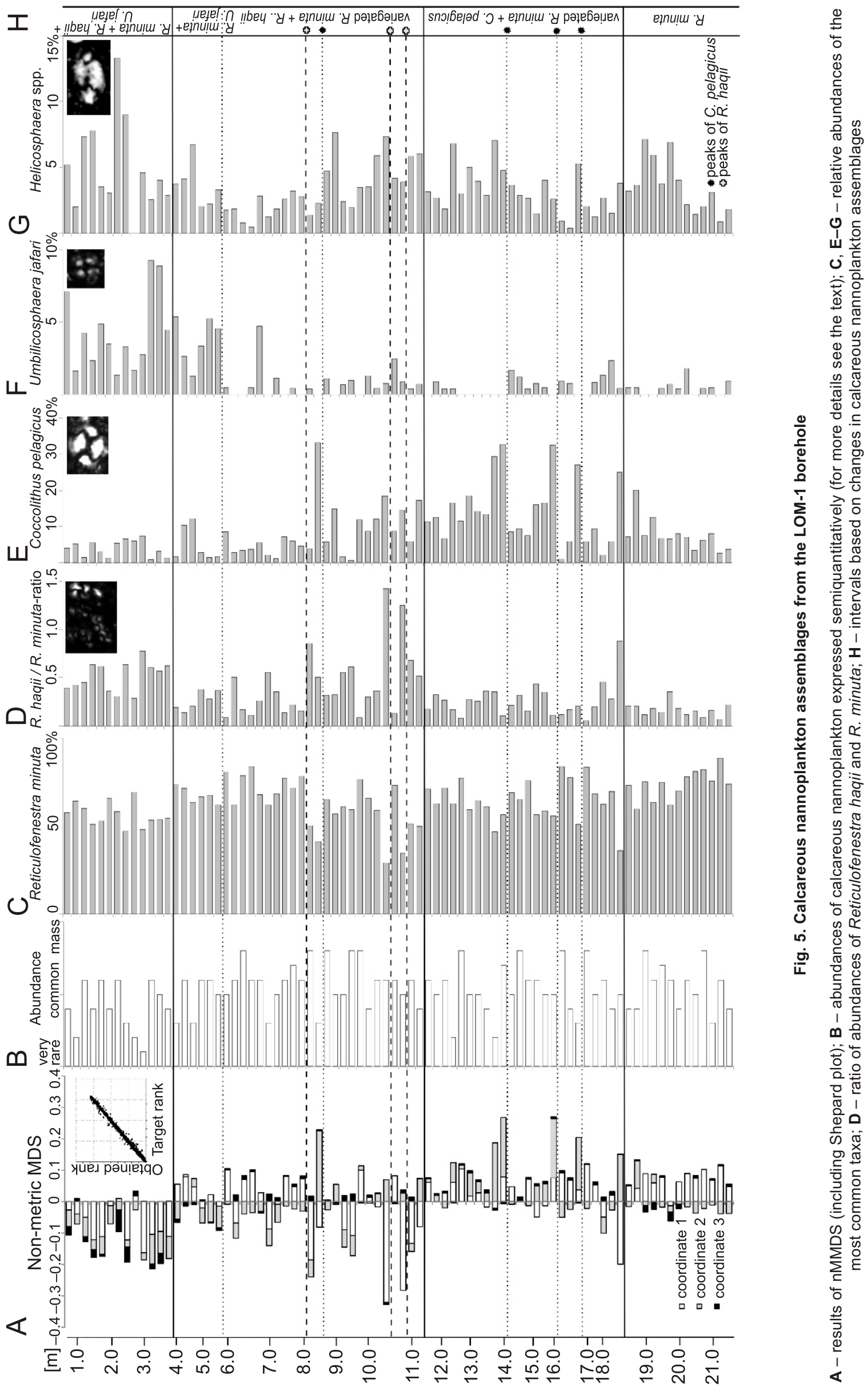




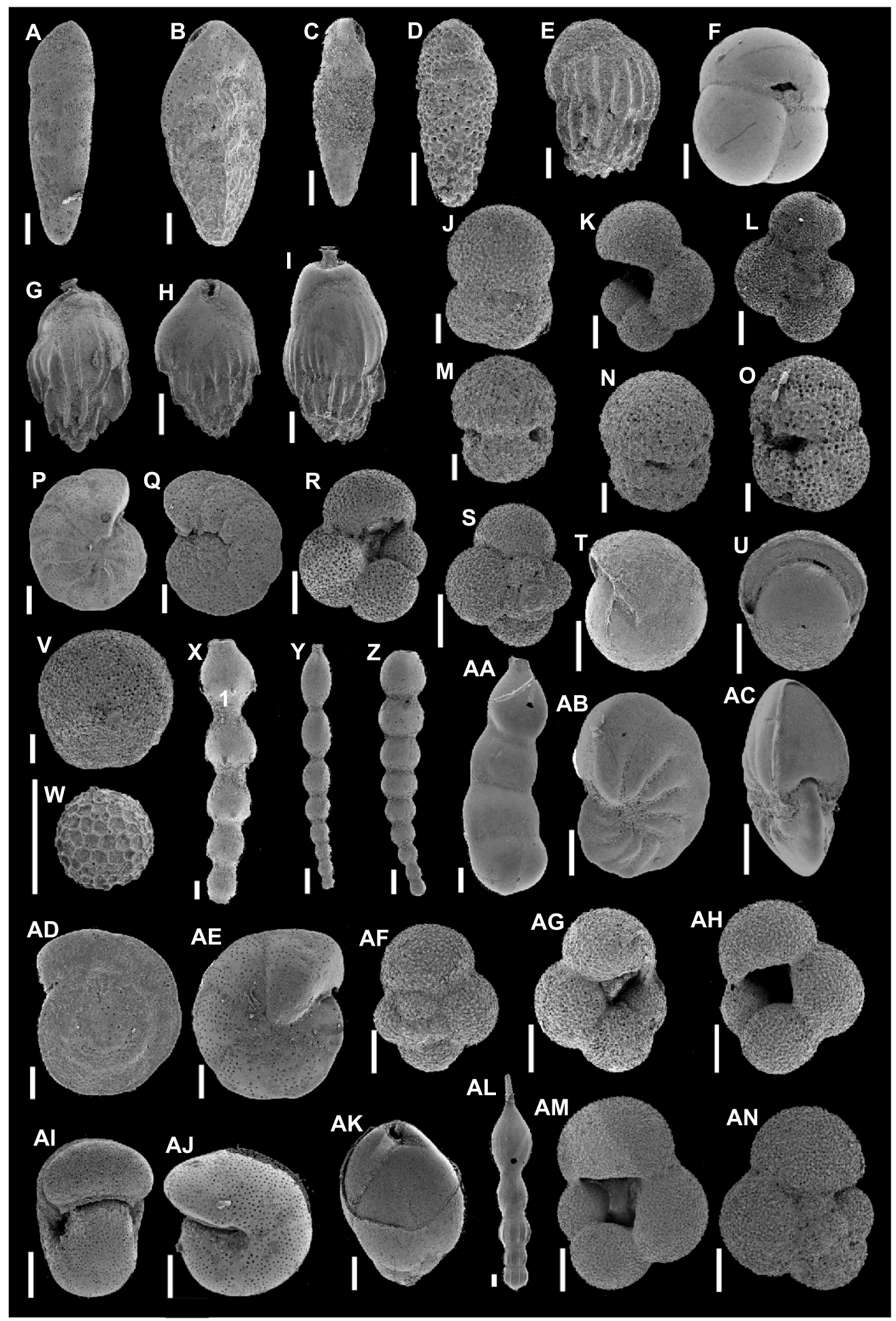

Fig. 6. Foraminifera from the LOM-1 borehole

A - Bolivina cf. lowmani Phleger \& Parker, 1951, 1.25 m; B - Bolivina dilatata Reuss, 1850, 1.25 m; C - Bolivina sp., 1.25 m; D - Bolivina plicatella Cushman, 1930, 1.25 m; E - Uvigerina macrocarinata Papp \& Turnovsky, 1953, 1.25 m; F - Sphaeroidina bulloides d'Orbigny, 1826, 1.25 m; G - Uvigerina macrocarinata Papp \& Turnovsky, 1953, 2.75 m; H - Bulimina striata d'Orbigny, $1826,2.75$ m; I - Uvigerina acuminata Hosius, 1895, 2.75 m; J - Globigerinoides bisphericus Todd, 1954, 2.75 m; K, L -Globigerinella regularis (d'Orbigny, 1846), $2.25 \mathrm{~m} ; \mathbf{M}, \mathbf{N}$ - Globigerinoides bisphericus, Todd, 1974, $2.75 \mathrm{~m}$; O - Globigerinoides trilobus Reuss, 1850, $2.75 \mathrm{~m} ; \mathbf{P}, \mathbf{Q}$-Cibicidoides ungerianus (d'Orbigny, 1846), $2.75 \mathrm{~m}$; R, S - Globigerina bulloides d'Orbigny, $1826,3.8 \mathrm{~m}$; T - Pullenia bulloides (d'Orbigny, 1846), $3.8 \mathrm{~m}$; U - Pullenia bulloides (d'Orbigny, 1846), 5.75 m; V - Orbulina suturalis Bronnimann, 1951, 8.75 m; W - Favulina hexagona (Williamson, 1848), $8.75 \mathrm{~m}$; $\mathbf{X}$ - Stilostomella adolphina (d'Orbigny, 1846), $9.75 \mathrm{~m}$; $\mathbf{Y}$ - Siphonodosaria consobrina (d'Orbigny, 1846 ), $9.75 \mathrm{~m} ; \mathbf{Z}$ Siphonodosaria scripta (d'Orbigny, 1846), 9.75 m; AA - Dimorphina akneriana (Neugeboren, 1851), 9.75 m; AB, AC - Nonion commune (d'Orbigny, 1846), 9.75 m; AD, AE - Heterolepa dutemplei (d'Orbigny, 1846), 12.0 m; AF, AG - Globigerina praebulloides Blow, 1959, $17.2 \mathrm{~m}$; AH - Globigerina praebulloides Blow, 1959, $19.5 \mathrm{~m}$; Al, AJ - Melonis pompilioides (Fichtel \& Moll, 1798), 19.5 m; AK Globobulimina puppoides (d'Orbigny, 1846), 20.2 m; AL - Amphicoryna badenensis (d'Orbigny, 1846), 20.2 m; AM, AN - Globigerina bulloides d'Orbigny,1826, 20.2 m. Length of scale bar $100 \mu \mathrm{m}$. Deposition of material: Department of Geology and Paleontology, Charles University in Prague 


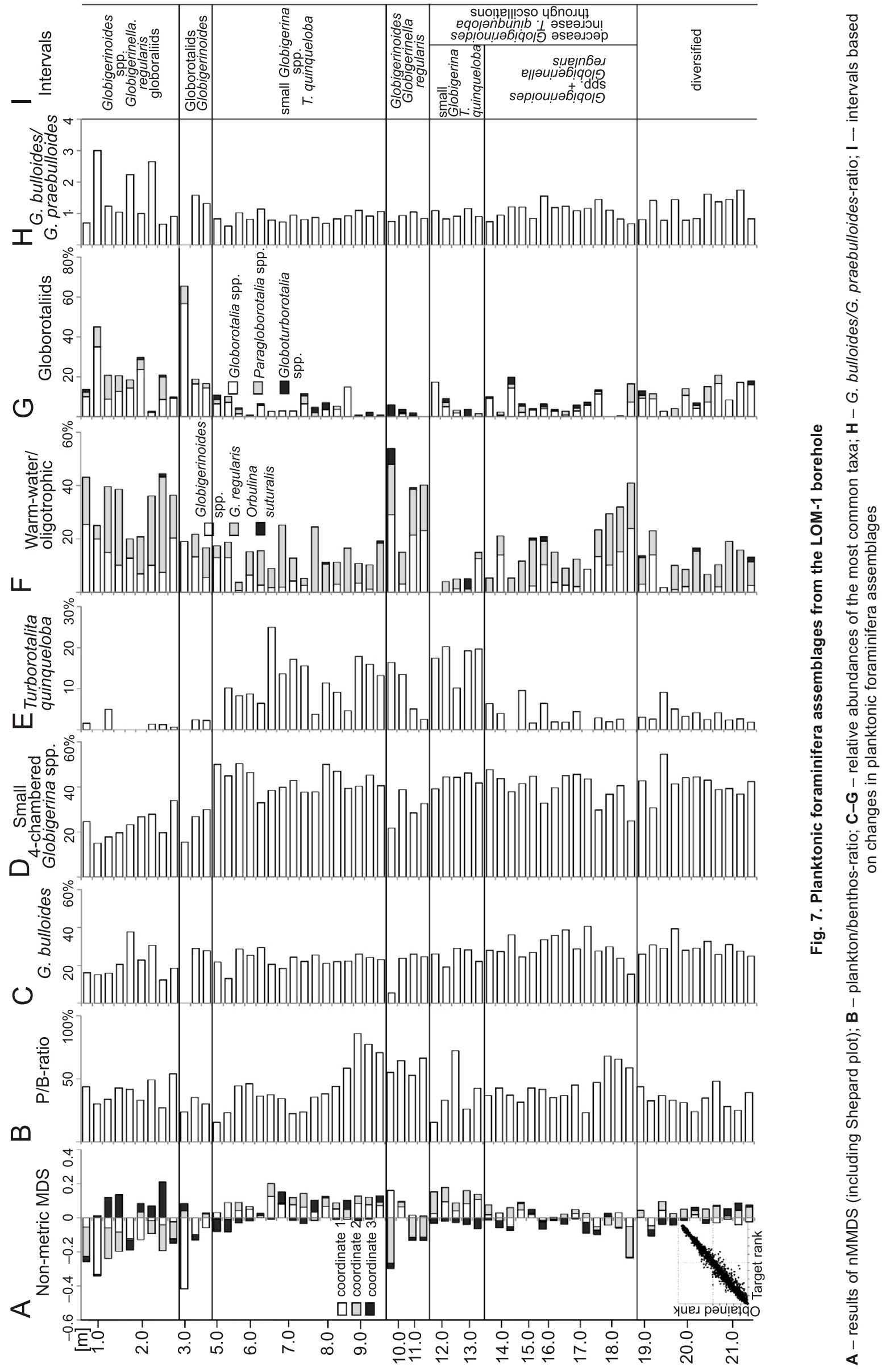



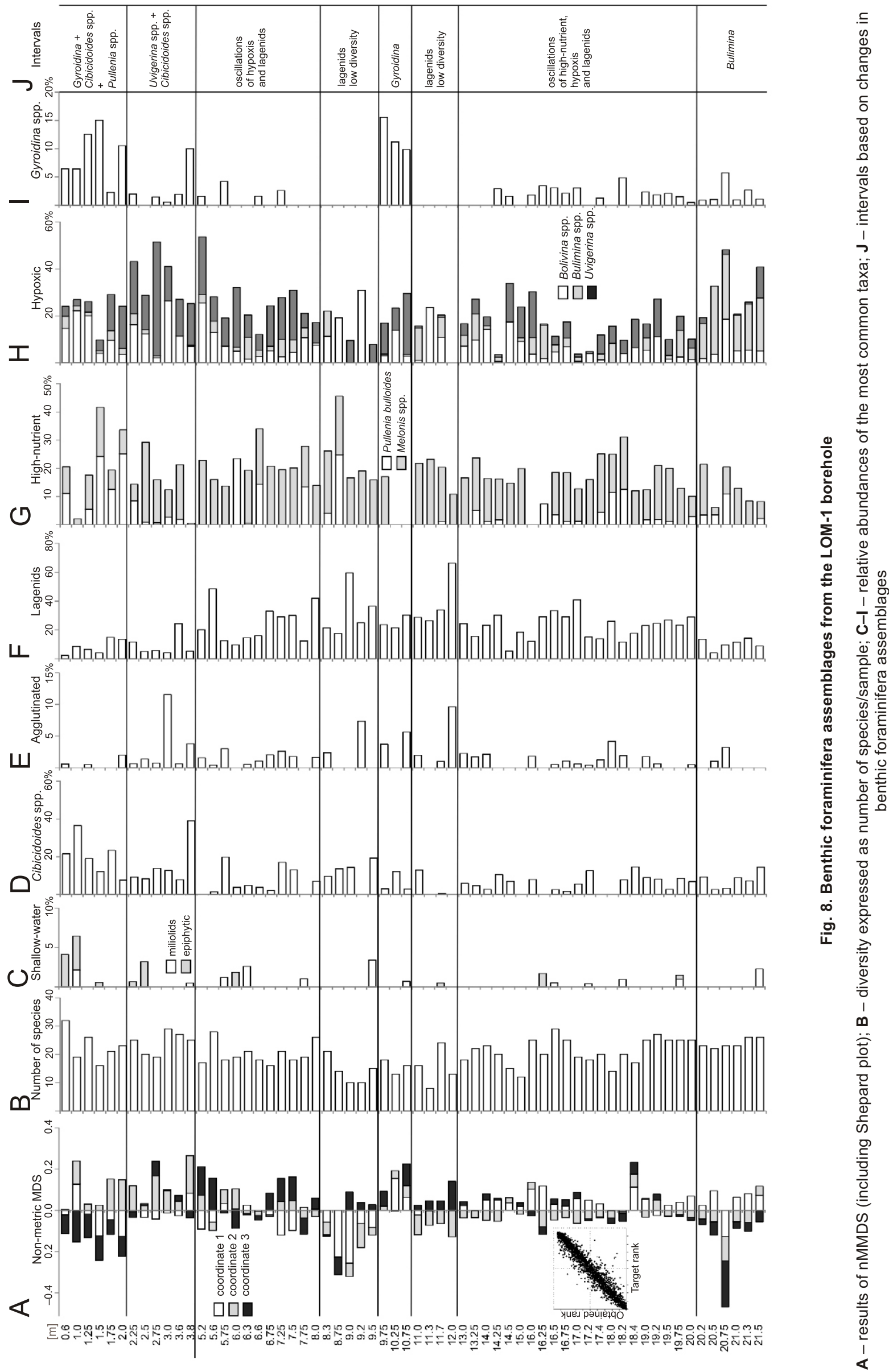

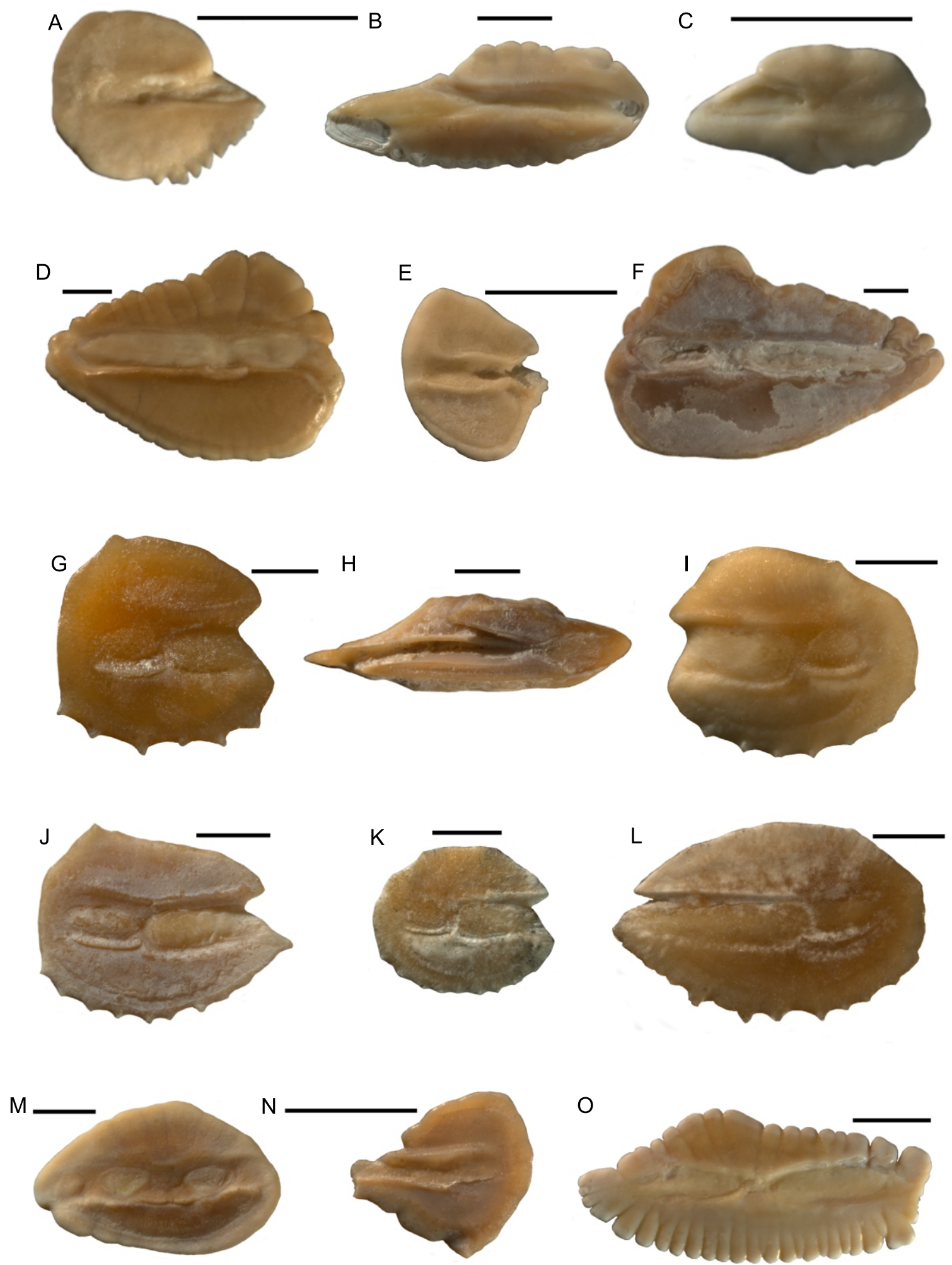

Fig. 9. Otoliths from the LOM-1 borehole (Badenian, Carpathian Foredeep, Moravia)

A-Bonapartia pedaliota Goode et Bean, 1896, L-15-16 m (DGS MU Inv. Nr. O 315); B - Nansenia sp., R - 6-7 m (DGS MU Inv. Nr. O 316 ); C - Etrumeus weileri (Smigielska, 1966), R - 0-1 ma (DGS MU Inv. Nr. O 317); D - Coelorincus coelorhinchus (Risso, 1810), L - 5-6 m (DGS MU Inv. Nr. O 318); E - Valenciennellus tripunctulatus (Esmark, 1871), L, 6-7 m (DGS MU Inv. Nr. O 319); F - Coelorincus macruruloides Brzobohaty, 1986, R-11-12 m (DGS MU Inv. Nr. O 320); G - Diaphus kokeni (Prochazka, 1893), L - 9-10 m (DGS MU Inv. Nr. O 321); H - Physiculus aff. huloti Poll, 1953, L - 15-14 m (DGS MU Inv. Nr. O 322); I - Diaphus regani Taaning, 1928, R - 1-2 m (DGS MU Inv. Nr. O 323); J - Diaphus acutirostrum (Holec, 1975), L - 1-2 m (DGS MU Inv. Nr. O 324); K - Diaphus cahuzaci Steurbaut, 1981, L 18-19 m (DGS MU Inv. Nr. O 325); L - Symbolophorus meridionalis Steurbaut, 1979, L - 16-17 m (DGS MU Inv. Nr. O 326); M - Gadiculus argenteus argenteus Guichenot, 1850, L - 5-6 m (DGS MU Inv. Nr. O 327); N - Maurolicus muelleri (Gmelin, 1798), R - 14-15 m (DGS MU Inv. Nr. O 328); O - Merluccius aff. merluccius (Linnaeus, 1758), R - 6-7 m (DGS MU Inv. Nr. O 329); all figures show inner views of otoliths; $\mathrm{L}$ - left otolith, R - right otolith; scale bar - $1 \mathrm{~mm}$. Deposition: Department of Geological Sciences, Masaryk University Brno (DGS MU) 
A

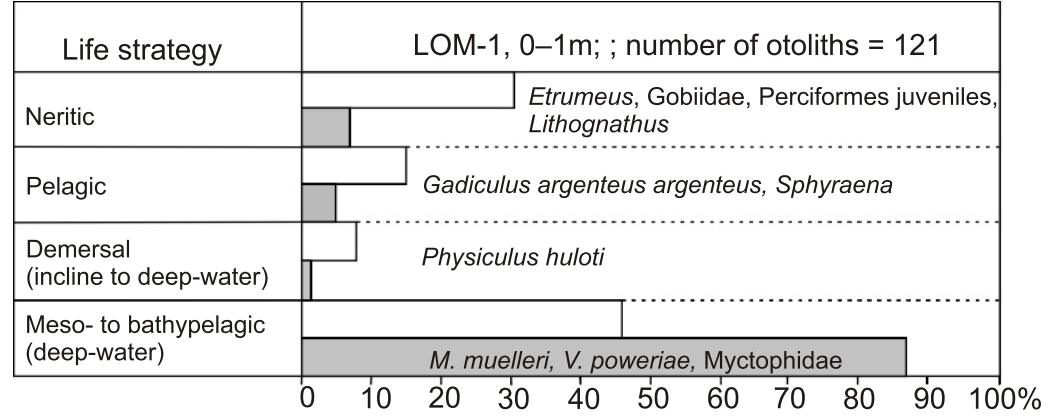

B

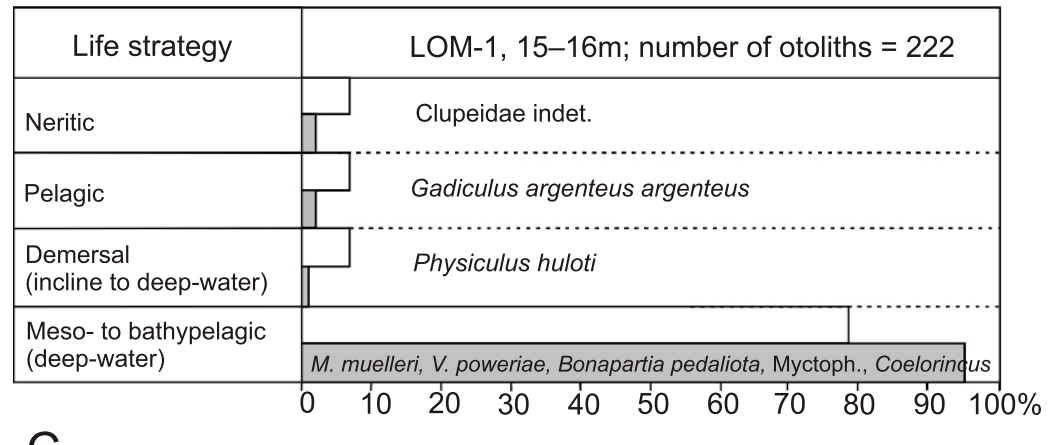

C

\begin{tabular}{|c|c|}
\hline Life strategy & LOM-1, 18-19m; number of otoliths $=310$ \\
\hline Neritic & Gobiidae \\
\hline Pelagic & Gadiculus argenteus argenteus \\
\hline \multirow{2}{*}{$\begin{array}{l}\text { Demersal } \\
\text { (incline to deep-water) }\end{array}$} & \\
\hline & Polyipnus, Merluccius, Hoplostethus, Physiculus huloti \\
\hline \multirow{2}{*}{$\begin{array}{l}\text { Meso- to bathypelagic } \\
\text { (deep-water) }\end{array}$} & \\
\hline & M. muelleri, V. poweriae, Myctophidae \\
\hline
\end{tabular}

$\%$ of taxa

$\%$ of individual otoliths

Fig. 10. Histograms of the otoliths according to life strategy in LOM-1

A - 0-1 m (number of otoliths = 121); $\mathbf{B}-15-16 \mathrm{~m}$ (number of otoliths = 222); C $-18-19 \mathrm{~m}$ (number of otoliths $=310$ )

2008), Orbulina (the first occurrence - FO 15.1 Ma: Gradstein et al., 2012; Mediterranean 14.6 Ma: Abdul Aziz et al.. 2008; Hüsing et al., 2010) and Sphenolithus heteromorphus (LO 13.53 Ma: Gradstein et al., 2012, Mediterranean area 13.419 Ma: Abdul Aziz et al., 2008; Hüsing et al., 2010) were recorded from the whole interval and Helicosphaera ampliaperta (LO 14.91 Ma; Gradstein et al., 2012) is missing. The top of the continuous occurrence of Helicosphaera waltrans (Last Common Occurrence - LCO at $14.357 \mathrm{Ma}$ in the Mediterranean area: Abdul Aziz et al., 2008) is recorded around the level $6.0 \mathrm{~m}$. Gradual decrease of its relative abundances in comparison with abundances of Helicopshaera walbersdorfensis is shown in Figure 2B. Based on the above-mentioned data, the

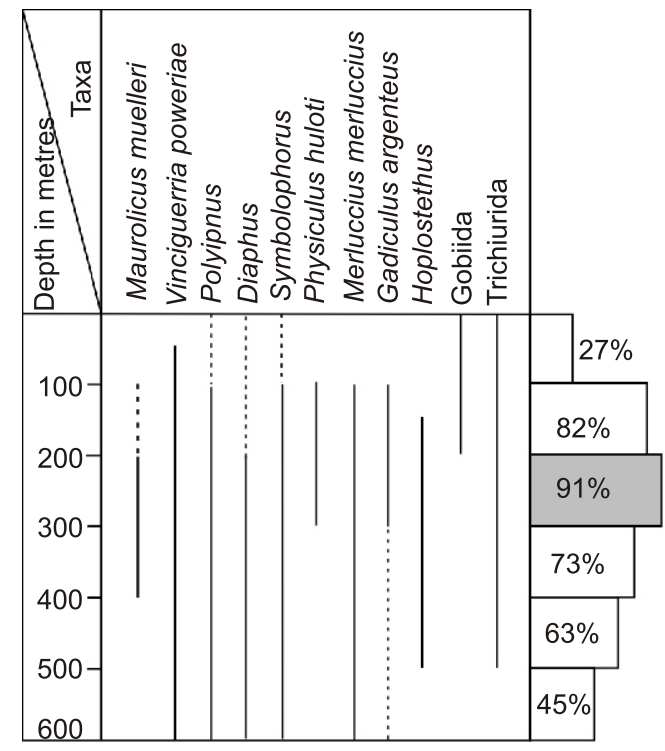

Fig. 11. Present-day bathymetric range of otolith taxa represented in LOM-1, 18-19 m interval

LOM section can be correlated with interval 14.6 $\mathrm{Ma}$ (the FO of Orbulina spp. in Mediterranean) to 13.42 $\mathrm{Ma}$ (the LO of Sphenolithus heteromorphus), though the upper boundary is probably older considering that, in Upper Silesian part of the Carpathian Foredeep Basin, the LO of Sphenolithus heteromorphus was recorded prior to the onset of Badenian evaporite deposition (Peryt, 1997) which is very well-constrained at 13.81 Ma (Leeuw et al., 2010).

\section{INTERPRETATION OF PALAEOENVIRONMENT}

Generally, the palaeoenvironment in the Lomnice area can be interpreted as a quiet marine environment of outer shelf to bathyal depths with high nutrient input. However, oscillations of palaeoenvironmental parameters are expected based on fluctuating abundances of individual taxa as well as $\mathrm{U}, \mathrm{Th}, \mathrm{K}$ oscillations and partly also lithological changes.

Based on the combined sedimentological, geochemical and palaeobiological records (Fig. 16), the section studied can be subdivided to the following intervals.

Interval 18.5-21.5 $\mathrm{m}$ (base) is formed by the monotonous facies M1. The upper part of the water column was characterized by Globigerina bulloides and the similar but smaller $G$. praebulloides which represent shallow-dwelling, herbivorous, opportunistic species blooming under a high-productivity regime (Schiebel et al., 1997). The size oscillations of Globigerina bulloides/praebulloides group (expressed as Globigerina bulloides/praebulloides-ratio; Fig. $7 \mathrm{H}$ ) reflect a variable environment with oscillating temperature and nutrient input (Malmgren and Kennett, 1978; Schmidt et al., 2004). Predominance of large specimens indicates rather high temperature and 


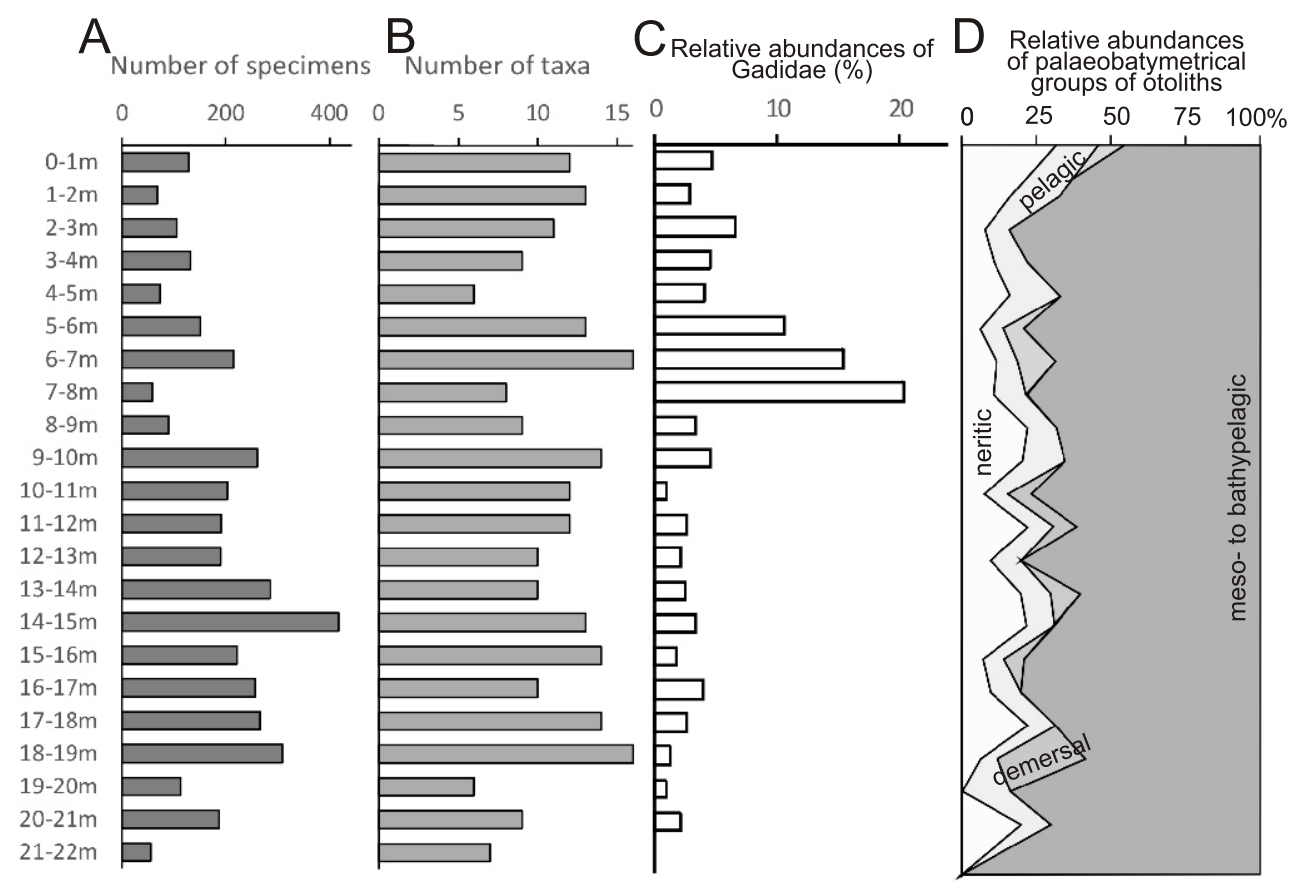

Fig. 12. Quantitative characteristics of otolith assemblages in the LOM-1 section

\begin{abstract}
A - abundance expressed as number of specimens in 1 metre of core; $\mathbf{B}$ - diversity expressed as number of taxa; $\mathbf{C}$ - relative abundances of Gadidae (Gadiculus argenteus) - a marker of the temperate climatic zone; D - palaeobathymetry based on relative abundance of fish species (otoliths)
\end{abstract}

mesotrophic conditions. Moreover, the co-occurrence of Turborotalita quinqueloba, Globorotalia bykovae and Globigerinella spp. with Globigerina spp. suggest a seasonal succession of assemblages (e.g., Reynold and Thunell, 1985; Rigual-Hernandez et al., 2012; Kuhnt et al., 2013; Salmon et al., 2014). The phytoplankton is dominated by Reticulofenestra minuta characterizing environmental stress with rapid changes within that environment, including oscillations of salinity (Wade and Brown, 2006), and nutrient content (Flores et al., 1997; Wells and Okada, 1997; Kameo, 2002) consistent with the varied test size of the Globigerina bulloides/praebulloides group. The increase of Coccolithus pelagicus at $19.5 \mathrm{~m}$ is traditionally considered as an indicator of cold, but mainly nutrient-rich water (Okada and Mclntyre, 1979; Winter et al., 1994; Cachao and Moita, 2000) and indicates here cooling and/or increase of nutrients from this level. The sea-floor was settled by the deep infaunal genus Bulimina spp. (20-21.5 m) associated with fine-grained sediments, high food availability, organic carbon content in the sediments and low oxygen (Miller and Lohman, 1982, Jorrisen et al., 1992; Murray, 2003). Its coexistence with small opportunistic oxyphilic Cibicidoides sp. (Kaiho, 1994) points to seasonal succession of populations or oxygenated sea-floor Cibicidoides spp. and hypoxy in sediment settled by infaunal Bulimina spp. Decrease of Bulimina spp. and increase of lagenids were recorded at $19.5 \mathrm{~m}$ which suggests an increase in oxygen content at the sea-floor. This event coinciding with the increase of $C$. pelagicus abundances indicating increase in nutrients and/or cooling in the surface water seems contradictory and can be explained by stratification of the water column and/or mixing of seasonal populations. At the same level, otolith diversity also increases, which might be related to increase of nutrients in the water column.

Gamma-spectrometric record showed gradual decline in the concentrations of $T h$, the value of $T h / K$ and $T h / U$ ratio and gradual increase in the concentrations of $U$ in the interval with Bulimina spp. (19.25-21.5 m). This part is terminated by a coincidence of relative low values of Th/K, Th/U, K and Th. It may be associated with dysoxic conditions and an increase in nutrients. The interval with lagenids is characterized by an irregular pattern of concentrations of Th and $U$. The concentrations of $\mathrm{K}$ are relatively stable within the entire interval $(\varnothing 1.2 \%$, SD 0.26$)$. The concentrations of both Th $(\varnothing 4.2 \mathrm{ppm}, \mathrm{SD} 0.8)$ and $U(\varnothing$ $3.0 \mathrm{ppm}, \mathrm{SD} 0.69$ ) are generally average compared with the results from the entire succession penetrated by the borehole.

Interval ca. $11-18.5 \mathrm{~m}$ is formed by the monotonous facies M1. At the base of this interval, the warm-water and oligotrophic planktonic foraminifera (Globigerinoides spp. and Globigerinella spp.) appeared abruptly, reflecting rapid warming or the influx of warm-water masses to the Carpathian Foredeep. Both warm-water genera are symbiont-bearing, shallow-dwellers occurring in subtropical and tropical areas (Bé, 1977; Reynolds and Thunell, 1985; Hemleben et al., 1989; Schiebel and Hemleben, 2005). The co-existence of these two genera may be explained using a Caribbean example: Globigerinoides spp. were recognized in autumn blooms with higher temperature and salinity variations, while Globigerinella spp. bloomed during spring with narrower temperature and salinity ranges (Schmuker, 2000). There is a co-incidence of Globigerina bulloides and Globigerinoides spp. with local wind-driven coastal upwelling areas (Conan et al., 2002), and this phenomenon cannot be excluded during deposition of this interval.

Based on the observation of Van der Zwaan et al. (1990), the high P/B-ratio recorded at the base of interval may indicate deepening though Hohennegeer (1995) excluded correlation between P/B-ratio and palaeodepth in the Central Paratethys Sea. However, otoliths also show the deepest sedimentational environment in this particular level from 17 to $19 \mathrm{~m}$ in agreement with increase in the P/B-ratio. 
A Calcareous nannoplankton

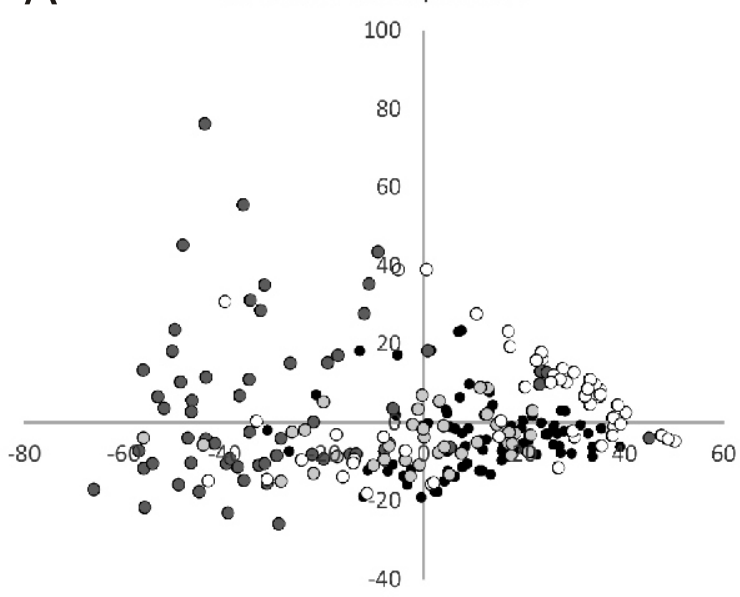

- LOM-1 O RY-1 O OV-1 O ZIDL-1+2

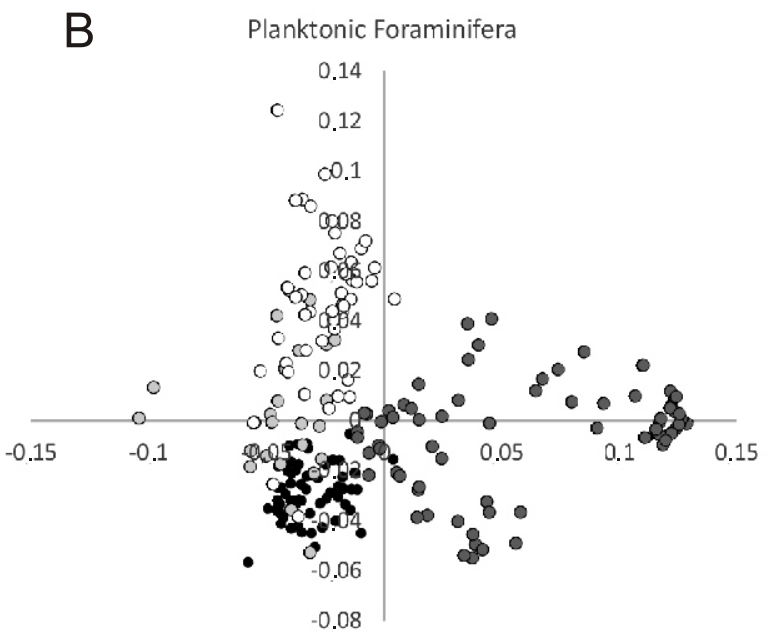

- LOM-1 0 RY-1 O OV-1 0 ZIDL-1+2

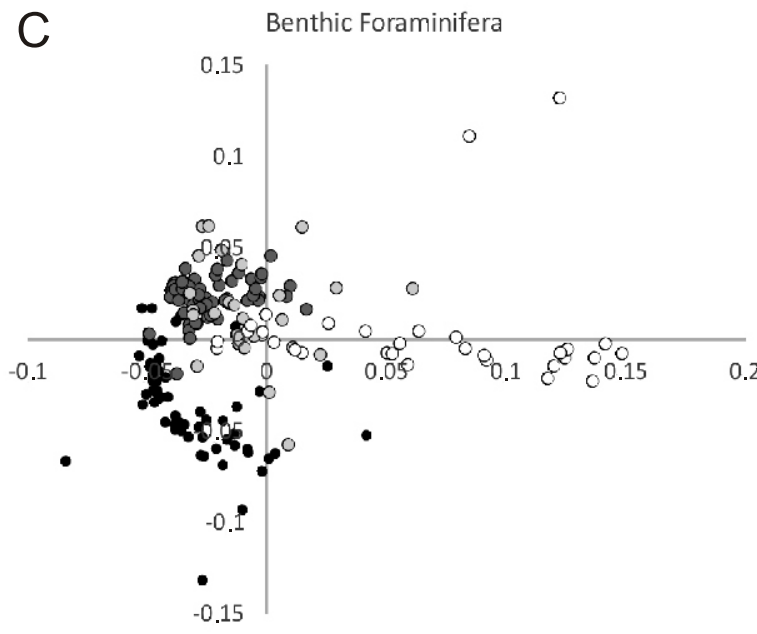

- LOM-1 - RY-1 O OV-1 O ZIDL-1+2

Fig. 13. Comparison of calcareous nannoplankton $(A)$ and foraminiferal assemblages $(B, C)$ from the Middle Badenian Carpathian Foredeep using the nMMDS
In the middle part of the interval (14-17 m), an increase of small Globigerina praebulloides and Coccolithus pelagicus (with peaks at 14 and $16 \mathrm{~m}$ ) is detected while the decrease in warm-water planktonic foraminifera indicates cooling and/or eutrophication. The increase in nutrients is supported also by abundant diatoms $(14-18.5 \mathrm{~m})$ and otoliths $(14-15 \mathrm{~m})$. Because there is a general agreement that here was no input of acidic volcaniclastic material (Nehyba, 1997; Nehyba et al., 1999), the source of $\mathrm{SiO}_{2}$ is probably exlusively derived from weathering of the adjacent crystalline basement.

High-nutrient markers dominated also at the sea-floor: Melonis is gradually substituted by the triserial high-nutrient markers Uvigerina and Bulimina around the level of $16 \mathrm{~m}$. Peaks of these high-nutrient markers (14 and $16 \mathrm{~m}$ ) correlate well with peaks of the eutrophic Coccolithus pelagicus. Studies of Recent Uvigerina as well as Melonis show that a high supply of organic material to the sediments and not the oxygen concentration in the bottom waters is the most important factor in controlling distribution of both genera (Caralp, 1989; Hermelin, 1992; Sjoerdsma and Van der Zwaan, 1992; Sen Gupta and Machain-Castillo, 1993; Miao and Thunell, 1993; Rathburn and Corliss, 1994). Then, abundant Uvigerina, Bolivina, Bulimina and Melonis typify regions of high organic productivity and a sustained flux of organic matter to the sea-floor, e.g., under areas of upwelling (Thomas et al., 1995) which can support an inference of seasonal upwelling from planktonic assemblages. However, our samples show alternations of deep infaunal Bulimina and Uvigerina with intermediate infaunal Melonis, which indicates different ecological requirements of these genera. There are more, partly contradictory explanations of this negative correlation between Melonis and Bulimina with Uvigerina from present seas. It may be explained by Schönfeld (2001) who recorded maximum abundances of Melonis under oxic conditions near the sediment surface where Melonis may indicate a high-nutrient but more oxic environment. The second possibility of substitutions of high-nutrient taxa in section may be variegated quality of organic matter (Caralp, 1989; Mojtahid et al., 2010). The nutrient capacity of organic matter of terrigenous origin is lowered during transport to the marine basin (Dumon and Grousset, 1977), while organic matter of marine origin produced during phytoplankton blooms often triggered by upwelling regime reached the sea-floor as high-quality organic matter (Caralp, 1989). Melonis prefer organic matter in a more altered form (terrigenous origin), Bulimina is indicative of high organic matter quality and quantity (marine origin; Caulle et al., 2014). However, Abu-Zied et al. (2008) suggested that Bolivina, Bulimina and Uvigerina are dependent on a rather continuous abundance of organic matter, that may be of a lower quality. Moreover, Jorissen et al. (1995) and Fontanier et al. (2002) questioned the high-nutrient preference of Melonis when recording that, with a decreasing organic input, the oxygenated layer expands, and under such conditions, intermediate infaunal taxa (such as Melonis) may become very successful. In any case, the substitution of Bulimina, Uvigerina and Melonis reflects variation in oxygen content and in quantity and quality of nutrients.

In the upper part of interval (11-14 $\mathrm{m}$ ) there is a marked increase in the abundance of Turborotalita quinqueloba as a shallow dweller marker of cold non-stratified waters (Rohling et al., 1993). Together with the abundant Coccolithus pelagicus they indicate cold surface water, though Helicosphaera spp. with peaks at 13.8 and $12.2 \mathrm{~m}$ has affinity to warmer, mesotrophic to oligotrophic water (Knappertsbusch, 1993; Ziveri et al., 1995, 2004) which may point to variation in quality of surface water masses. The productivity of diatoms decreases. At the sea-floor, low-oxic foraminifera are substituted 

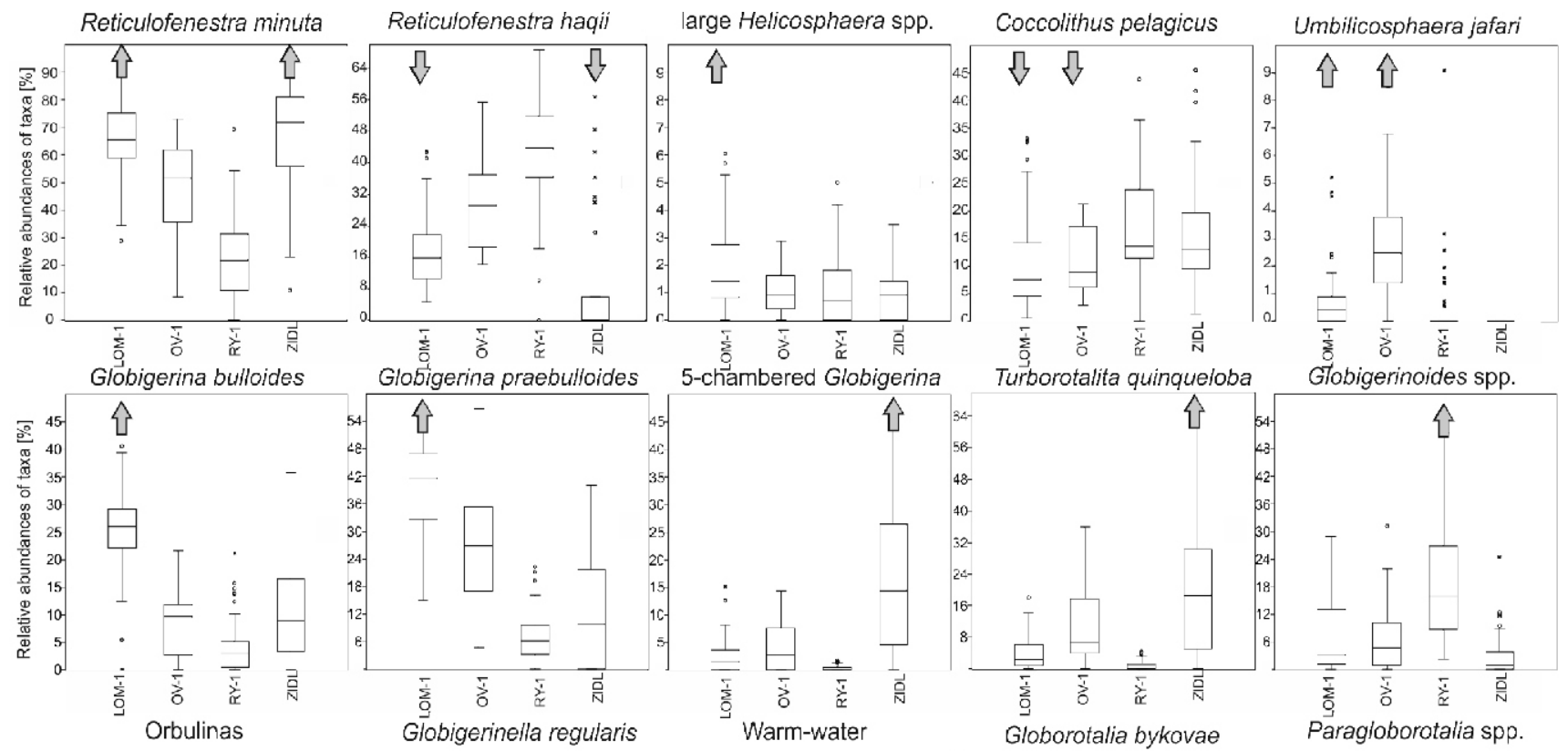

5-chambered Globigerina
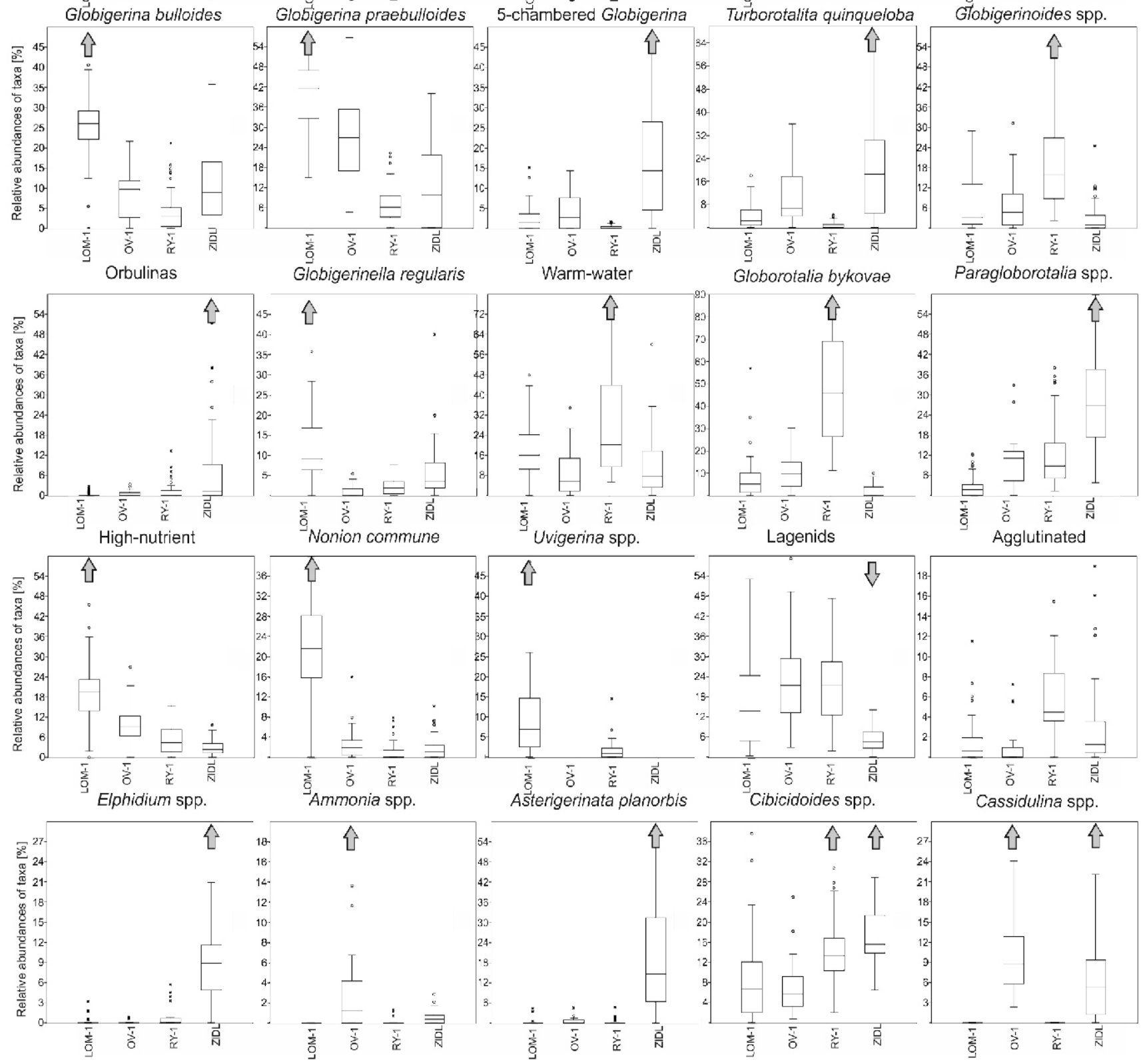

Fig. 14. Differences in composition of foraminiferal and calcareous nannoplankton assemblages in the boreholes LOM-1, OV-1, RY-1 and ZIDL-1+2 from the Middle Badenian Carpathian Foredeep in Moravia

Differences significant by Kruskall-Wallis tests are indicated by arrows 
A

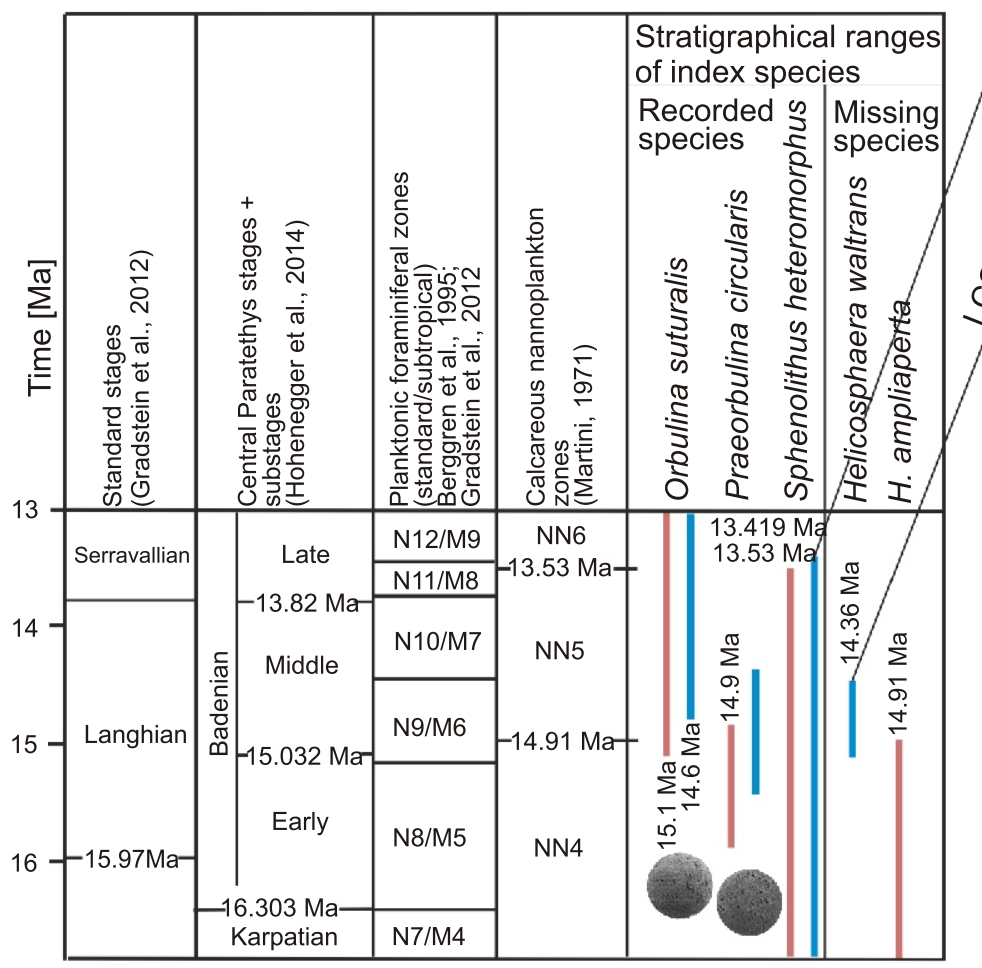

Stratigraphical ranges of index species:

world oceans (Gradstein et al., 2012)
B

0

5

10 15

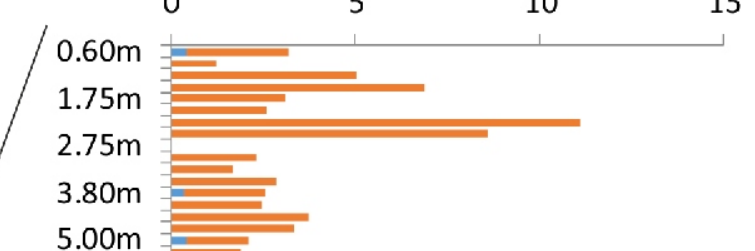

Mediterranean area (Abdul Aziz et al., 2008; Di Stefano et al., 2008; Hüsing et al., 2010)

Fig. 15A - stratigraphical correlation of the LOM-1 borehole; B - changes in relative abundances of biostratigraphical markers Helicosphaera waltrans and $H$. walbersdorfensis

by monoserial lagenids (infaunal deposit feeders; Murray, 2006) and textulariids (mainly detrivore Kareriella associated with mud and silt substrate; Murray, 2006). In general, a dominance of agglutinated species reflects the oligotrophic character of the benthic ecosystem (Jorissen et al., 1998). Thus, the upper part of interval can be interpreted as a cold interval with slightly decreased nutrient input and increased oxygen content at the sea-floor.

The irregular pattern of concentrations of Th $(\varnothing 3.6 \mathrm{ppm}$, SD 1.1) and $U(\varnothing 2.9 \mathrm{ppm}, \mathrm{SD} 0.81)$, and values of both $\mathrm{Th} / \mathrm{K}$ and $\mathrm{Th} / \mathrm{U}$ ratios, typical of this interval, corroborated the interpretation of oscillations of oxygen and nutrients. A maximum of nutrients is expected between 14 and $16 \mathrm{~m}$, which agrees with the highest abundances of otoliths as well as of diatoms. Seasonality could have led to local coastal (wind-driven) upwelling as a source of nutrients due to southward winds (western coast in northern hemisphere; Longhurst, 2010). The interval of expected maximum nutrient levels is characterized by coincidence of relative high concentrations of $U$ and relative low concentrations of Th and also the lowest $\mathrm{Th} / \mathrm{K}$, Th/ $\mathrm{U}$ values in the entire LOM-1 profile. The concentrations of $\mathrm{K}(\varnothing) .9 \%$, SD 0.25$)$ are relatively stable. The relative low concentrations of $\mathrm{K}$ and the value of the Th/K ratio in the interval $13-15 \mathrm{~m}$ could be a signal of the presence of kaolinite in the clay fraction instead of illite and of the prevalence of humid conditions in the source area (Rider, 1999). Increased humidity may increase riverine input as a source of terrigenous nutrients (phytodetritus). The irregular pattern of concentrations of Th $(\varnothing 4.4$ $\mathrm{ppm}, \mathrm{SD} 1.65$ ) and of the $\mathrm{Th} / \mathrm{K}$ ratio is typical of the upper part of the interval where nutrient input decreased and oxygen content increased. The concentrations of $U$ ( $\varnothing 3.7$ ppm, SD 0.64), the values of the $T h / U$ ratio and especially the concentrations of $\mathrm{K}(\varnothing 1.0 \%, \mathrm{SD} 0.27)$ are relatively stable in this part of the interval. The concentrations of Th and $U$ are generally higher.

Interval $\mathbf{1 0 - 1 1 ~} \mathbf{m}$ is very pronounced, formed by facies M1. The relative abundance of warm-water planktonic foraminifera and the $\mathrm{P} / \mathrm{B}$ ratio markedly increase and diatoms disappear at the base of the interval, which may indicate warming. The increased abundances of the species Reticulofenestra haqii showing negative correlation with Coccolithus pelagicus corroborates interpretation of warm oligotrophic conditions in the surface water. At the sea-floor Sphaeroidina bulloides markedly prevails. Unfortunately, there is not much known of its palaeoecological preferences. The rather inconsistent published data about the ecology of the Sphaeroidina spp. (cosmopolitan deep-water taxa - Van Morkhoven et al., 1986; semi-infaunal omnivore - Murray, 2006; epifaunal, suboxic - Drinia et al., 2007; marker of high dissolved oxygen and low organic carbon levels - Hayek and Wilson, 2013) rather oligotrophic, oxic, deeper-water conditions are possible to interpret. Otolith assemblages showed a peak of meso- to bathypelagic and pelagic taxa in the interval 10-11 m (Fig. 12D). Generally, sediments were deposited during a warm, oligotrophic period probably accompanied by deepening. The highest concentrations of both $\mathrm{K}$ and Th were recognized in the sample from the depth $10.83 \mathrm{~m}$ and the highest concentration of $\mathrm{U}$ and also the lowest ratio of $\mathrm{Th} / \mathrm{U}$ in the next sample from $10.44 \mathrm{~m}$. This can be interpreted as a signal of the most distal (the deepest?) condition, 


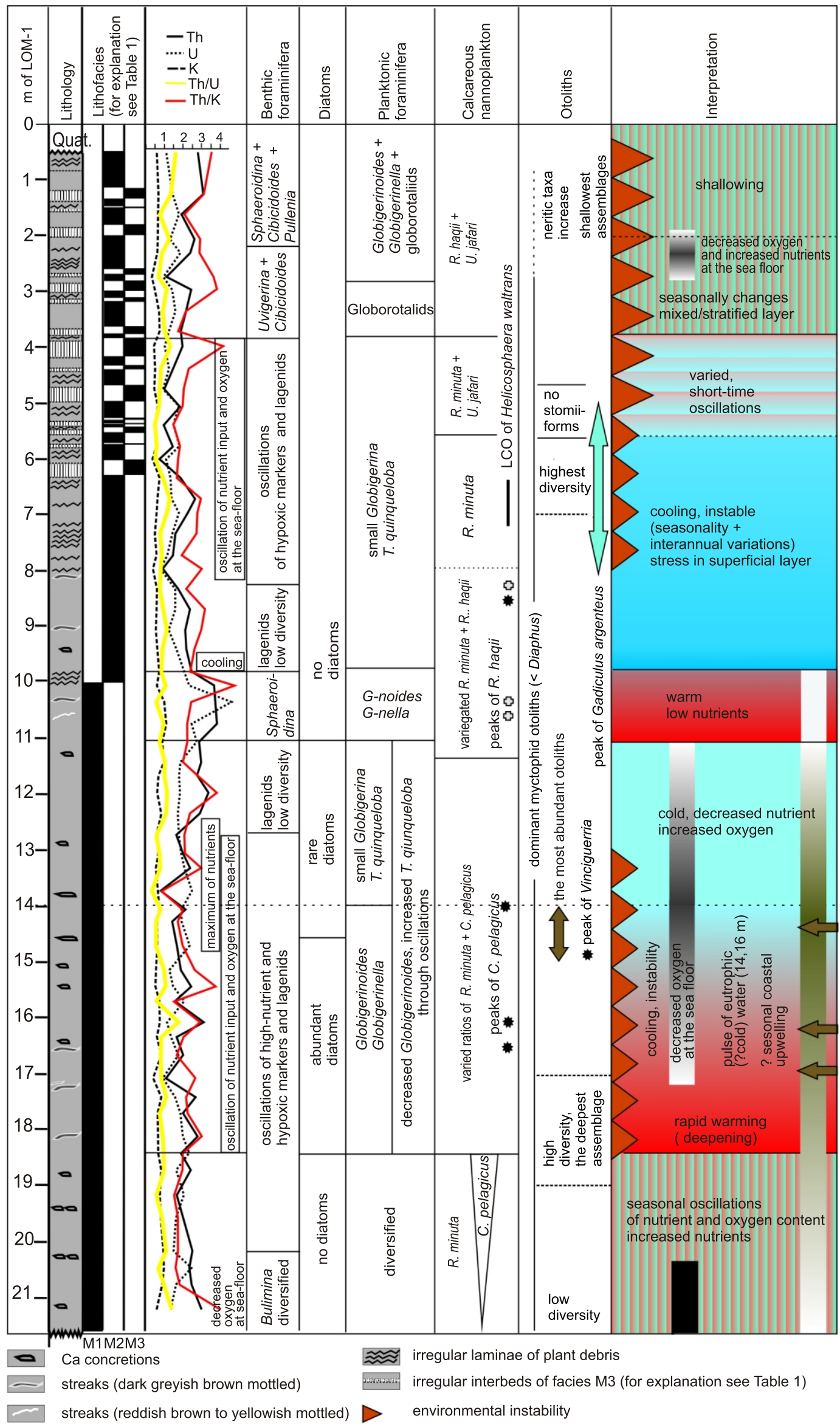

Fig. 16. Summary of all sedimentological, geochemical and palaeobiological records 
with a minimum of clastic delivery. The maximum flooding surface (MFS) is situated in this interval (Berstad and Dypvik, 1982). Generally the highest concentrations of $U$ ( $\varnothing 5.6 \mathrm{ppm}$, SD 2.49), Th ( 6 6.6 ppm, SD 1.13) and also $\mathrm{K}(\varnothing 1.3 \%, \mathrm{SD}$ 0.42 ) were recognized in samples from this interval, as were the highest variations in the contents of $\mathrm{K}$ and $\mathrm{U}$. The sedimentary succession below the suggested MFS could be tentativlely interpreted as a transgressive systems tract (TST), whereas the one above the MFS as a highstand systems tract (HST). Moreover the turnover in the trend of concentrations of natural radioactive elements is connected with this interval. A general increase in $\mathrm{U}$, Th (also partly in $\mathrm{K}$ ) and $\mathrm{Th} / \mathrm{K}$ can be followed from the depth of about $14 \mathrm{~m}$ (lowest $\mathrm{Th} / \mathrm{K}$ and $\mathrm{Th} / \mathrm{U}$ ) towards the depth 10.44-10.83 m. Afterwards a significant decline in U, K and Th concentrations was recorded. Coincidence of: (a) increase in humidity followed by increased aridity (Th vs. K kaolinite vs. illite), and (b) increase of nutrient delivery followed by its decrease (concentrations of $U$ ) significantly affected the biota. We can speculate about a change in the systems of currents (termination/reduction of upwelling?) and postulate that such an event may be detectable in the adjacent parts of the basin.

Interval $\mathbf{5 . 6 - 1 0 ~} \mathrm{m}$ is formed by facies M2 and the upper part of the interval is formed by alternations of facies M2 and M3. A sharp and irregular contact with facies M2 corresponds with the lower boundary of the interval and agrees well with the sudden change in the micropalaeontological record. Surface water was characterized by abundant stress-tolerant Reticulofenestra minuta and Globigerina praebulloides and oscillations in abundances of Turborotalita quinqueloba suggesting stress in surface water including oscillations of nutrient, temperature and/or salinity. Small peaks of warm-water planktonic foraminifera $(6.75,7.75$ and $8.75 \mathrm{~m}$; Fig. 7) coincide with decreases in abundances of cold-water $T$. quinqueloba indicating temperature fluctuations. The peaks of high-nutrient benthic foraminifera at 8.75, 7.75 and $6.6 \mathrm{~m}$ (Fig. 8) can be correlated with peaks of warm-water planktonic foraminifera which is surprising and may indicate stratification of the water column. In this case the high-nutrient foraminifera are also dysoxia-tolerant, thus successful in such an environment. In the deeper part of the water column, a significant increase in the number of individuals of the cryophilic fish species $G$. argenteus argenteus in the interval of 6-7 m indicates cold water masses. Generally, this interval represents a varied palaeoenvironment with temperature, nutrient and probably also salinity oscillations mainly in surface water. In deeper water, more stable cold water masses are expected due to at least seasonal stratification of the water column. In this interval the lowest concentrations of $U$, $\mathrm{K}$ and Th in the entire LOM-1 profile were recognized. But generally irregular pattern of concentrations of Th $(\varnothing 3.1 \mathrm{ppm}, \mathrm{SD}$ 1.11), U (Ø $2.3 \mathrm{ppm}, \mathrm{SD} 0.55)$ and of the $\mathrm{Th} / \mathrm{K}$ ratio can be seen. The concentrations of $\mathrm{K}(\varnothing 0.7 \%$, SD 0.22$)$ and value of $\mathrm{Th} / \mathrm{U}$ ratio are much stable. The lowest concentrations of $\mathrm{K}$ and the value of $\mathrm{Th} / \mathrm{K}$ ratio are connected with a gradational transition from facies M2 to M3 and may be a signal of increased humidity in the source area (Rider, 1999). However, in agreement with the varied lithology as well as with the micropalaeontological record, variable rainfall is expected to correspond with extreme climate events deduced from the strongly negative excursions in $\delta^{18} \mathrm{O}$ and $\delta^{13} \mathrm{C}$ in the Ostrea isotope archive (Harzhauser et al., 2011) and from the irregular appearance of clastic intercalations in limestone bodies (Holcová et al., 2015). These instabilities may be reflected by the irregular pattern of the $\mathrm{Th}, \mathrm{U}$ and $\mathrm{Th} / \mathrm{K}$ ratios.

Interval 3.8-5.6 $\mathrm{m}$ is formed by alternation of facies $\mathrm{M} 2$ and M3 and can be characterized by the appearance of
Umbilicosphaera jafari and Reticulofenestra minuta. Umbilicosphaera spp. showed affinities to warmer (mean annual temperature under $15^{\circ} \mathrm{C}$ ) rather oligotrophic water (Ziveri et al., 2004; Boeckel et al., 2006). Boeckel et al. (2006) described its tolerance to saline water. Small stress-tolerant Globigerina praebulloides which prevailed over large Globigerina bulloides may indicate also stress including salinity oscillations. Benthic foraminifera do not change in the interval boundary but peaks of lagenids at $5.6 \mathrm{~m}$ and hypoxic taxa at $5.2 \mathrm{~m}$ were recorded. At the base of the interval, the LO of Helicosphaera waltrans was recorded. The event can be correlated with the first signals of the Middle Miocene Climatic Transition manifested in the study area by decreased riverine input due to aridification causing increase in salinity and decrease in nutrients (Holcová et al., 2015) which can correspond with palaeoenvironmental changes represented in the upper part of the interval. The results of gamma spectrometry are very similar in the lower interval i.e. an irregular pattern of concentrations of Th $(\varnothing 2.7 \%$, SD 0.77) and U ( $\varnothing 2.2$ ppm, SD 0.58) and stable concentrations of $\mathrm{K}(\varnothing 0.7 \%$, SD 0.23$)$.

Interval top of borehole $\mathbf{- 3 . 8} \mathbf{m}$ is characterized by high though varied abundances of Umbilicosphaera jafari and Reticulofenstra haqii; which indicate oligotrophic conditions with salinity oscillations probably due to hypersaline conditions. Cold-water Turborotalita quinqueloba practically disappears at the base of the interval, and large Globigerina bulloides prevailed over small $G$. praebulloides though their ratio strongly varies which agrees with oscillations in the nannoplankton assemblages. Increase of globorotaliid abundances is followed by peaks of warm-water planktonic foraminifera at 2-2.75 m; $1.25-1.5 \mathrm{~m}$ and $0.6 \mathrm{~m}$. From $2 \mathrm{~m}$ upwards again there is an increased abundance of globorotaliids. Globorotalia spp.-dominated planktonic foraminifera assemblages similar to those of this interval appear seasonally in oligotrophic areas during cold months (the Gulf of Mexico - Poore et al., 2013; Sargasso Sea - Salmon et al., 2014). In the midlatitude Atlantic, globorotaliids together with Turborotalita quinqueloba are associated with spring blooms while Globigerinella spp., Orbulina spp. and Globigerinoides spp. are restricted to the summer warm and well-stratified ocean (Chapman, 2010). Despite these differences in different climatic zones, planktonic foraminifera in this interval can be well explained by seasonal succession of populations. Lack of cold-water T. quinqueloba suggests a subtropical climate. This interval is formed by alternations of facies M2 and M3. The results of gamma spectrometry are very similar for the two lower intervals i.e. an irregular pattern of concentrations of Th $(\varnothing 4.2 \%$, SD 1.13) and $U(\varnothing 2.5 \mathrm{ppm}, \mathrm{SD} 0.52)$ and stable concentrations of $\mathrm{K}(\varnothing 0.8 \%$, SD 0.23$)$. The concentrations of $\mathrm{K}, \mathrm{U}$ and Th are generally lower for the succession above the proposed MFS (upper three intervals) than for the succession below it.

At the sea-floor, peaks of Cibicidoides showed oxic conditions, however, its co-occurrence with hypoxic foraminifera, mainly Uvigerina spp., indicate seasonality. At the top of the borehole, the highest relative abundance of shallow-water benthic species was recorded, supporting an interpretation of shallowing. Increased number of otoliths of neritic species iare clearly visible in the highest part of the profile $(0-1 \mathrm{~m})$ in accordance with the interpreted shallowing.

These intervals can be compared with intervals that reflect orbital forced climatic changes defined in isochronous sections of the Central Paratethys, e.g. Sooss (Hohenegger et al., 2008) and Rybníček (Kopecká, 2012).

The association of otoliths is broadly consistent with this interpretation. Accuracy comparison with other groups is, however, limited by the frequency of otoliths. That is statistically sig- 
nificant especially in samples from the 9-19 m levels (with 200-400 individuals, see Fig. 12), while other levels of the borehole show lower numbers of otoliths (samples of 7-8 $\mathrm{m}$ and 21-22 m levels with only 51 or 56 otoliths respectively).

A frequency diagram of species of bony fish showing their living environment (Fig. 11) is also divided into seven levels that roughly correspond to the intervals defined and discussed above. This development indicates that some interpreted changes and trends may also reflect variable bathymetry within the depth range of the higher bathyal zone. An increased number of neritic species is clearly visible in the highest part of the profile $(0-1 \mathrm{~m})$ in accordance with the interpreted shallowing. Otoliths indicate the deepest sedimentation at the base of the borehole and in particular from 17 to $19 \mathrm{~m}$.

Relatively high numbers of the otolith $G$. argenteus argenteus in the intervals of $16-17 \mathrm{~m}$ and $13-15 \mathrm{~m}$ is in accordance with colder episodes suggested by foraminifera and nannoplankton. A significant increase in the number of individuals of this cryophilic species in the interval of 6-7 $\mathrm{m}$ is, however, at the LCO boundary of Helicosphaera waltrans. This entirely agrees with the expected first signal of the Middle Miocene Climatic Transition in the depth of $5.6 \mathrm{~m}$ and may indicate its somewhat earlier onset in the profile studied. Otherwise the conspicuous absence of more or less continuous stomiiform otoliths at the depth interval of $4-5 \mathrm{~m}$ is difficult to interpret.

\section{SPECIFICITY OF PALAEOENVIRONMENT RECORDED IN THE LOMNICE DENUDATION RELICT}

The Lomnice locality offers, from the point of the palaeogeography of the Carpathian Foredeep and classical models of peripheral foreland basins, a possibility to study the deposits of the distal part of the basin along its passive margin. The almost monotonous, $>20 \mathrm{~m}$ thick succession of clayey silts reflects on the other hand a relatively deep-water depositional environment, which is more typical of the relatively more proximal parts of the peripheral foreland basin (distal foredeep depozone sensu DeCelles and Giles, 1996).

Based on differences in foraminifera and calcareous nannoplankton assemblages (Figs. 10 and 11), the specificity of the Lomnice area is expressed by high abundances of high-nutrient markers at the sea-floor (Melonis, Pullenia, Nonion ex gr. commune, Uvigerina) and Globigerina bulloides and $G$. praebulloides in surface water. As we discussed in the previous section, those assemblages may indicate local wind-driven coastal upwelling (Longhurst, 2010). This source of nutrient is also consistent with the lack of the Cassidulina group which indicates a strong influence of seasonal phytodetritus pulses (Gooday, 1993). Another argument to support the hypothesis of local upwelling is high abundances of Nonion which are associated with highly eutrophic condition of high-quality organic matter (Mojtahid et al., 2010). Such material is of marine origin produced during phytoplankton blooms often triggered by an upwelling regime (Caralp, 1989). The Lomnice area was situated in the western coast of the Carpathian Foredeep sea (in the northern hemisphere) and therefore southwards directed winds must have triggered upwelling. In this case, generally downwelling seasonal circulation may be expected at the east coast (Židlochovice) where 5-chambered Globigerina and Turborotalita quinqueloba dominated instead the Globigerina bulloides/praebulloides group. The prevalent deep-dweller Globorotalia bykovae in the Rybníček area may indicate the deepest part of the basin.

Among warm-water planktonic foraminifera characterizing the summer period with a stratified layer Globigerinella pre- vailed in the Lomnice area while Orbulina and Globigerinoides are concentrated in the Rybniček area. Generally, comparable environmental requirements are expected for all three genera, but narrower temperature and salinity tolerances are considered for Globigerinella (Bijma et al., 1990; Schmuker, 2000). This might indicate more stable conditions (mainly salinity oscillations) during summer stratification in surface water in the Lomnice area by comparison with the central part of the basin. It corresponds to the palaeobathymetry of the Carpathian Foredeep based on otoliths (Brzobohatý, 1997, 2001).

A lack of shallow-water taxa indicates an outer shelf to bathyal environment in the Lomnice area without transport of shallow-water elements which is comparable with the Rybníček area. This agrees with the interpretation of quiet offshore sedimentation.

\section{CORRELATION WITH OTHER CENTRAL PARATETHYS BASINS}

The time interval studied represents, sensu Hohenegger et al. (2014), the Middle Badenian transgression correlable with the Middle Miocene sea level cycle TB 2.4 (Haq et al., 1988). Biostratigraphically this can be defined by the co-ocurrence of Orbulina and Helicosphaera waltrans. This interval was recognized in the Central Paratethys in the Danube Basin in Slovakia (Ozdinová, 2008), Slovenia (Bartol, 2009) and the Vienna Basin (Švábenická, 2002). In the Carpathian Foredeep it is concentrated in its southern and central part (Švábenická, 2002). Helicosphaera waltrans is lacking in Poland (Oszczypko and Oszczypko-Clowes, 2012), eastern Hungary (Selmeczi et al., 2012) and the northern part of the Pannonian Basin in Slovakia and these transgressive deposits should be younger than 14.37 Ma (LCO of $H$. waltrans). This could indicate heterechroneity of this transgression in a SW to NE direction (?through tectonical influences). Selmeczi et al. (2012) supported this hypothesis when magnetostratigraphical results showed different ages for the Middle Miocene transgresion between western and eastern Hungary.

Unfortunatelly, palaeoecological data comparable with the data presented here are sparse. Results from the Badenian stratotype area, Sooss, are comparable although slightly younger. As in our results, Hohenegger et al. (2008) described an alternation of warm and cold intervals with a general cooling trend. Peryt (2013) also, in slightly younger strata, showed that comparable oxygenation and productivity changes preceded the "Badenian salinity crisis" in the Polish part of the Carpathian Foredeep. Though the marine history finished earlier in Moravia, and deposition of evaporites have not been recorded here, the impact of climatic changes preceding the salinity crisis on the marine palaeoenvironment is very similar in both areas of the Carpathian Foredeep.

\section{CONCLUSIONS}

1. The Lomnice denudational relict is located in the distal part (forebulge depozone) of the Carpathian Foredeep Basin. Borehole LOM-1 recorded a quiet environment of the outer shelf to upper bathyal zone of monotonous clayey silts, which are more typical of the more proximal parts of a peripheral foreland basin. This suggests that the Badenian flooding had to be extended farther inland towards the passive margin.

2. Specificity of the environment is manifested by high abundances of the benthic high-nutrient markers Nonion and Uvigerina as well as Globigerina bulloides and G. praebulloides group among plankton. These foraminifera required high nutri- 
ent levels preferably of marine origin produced during phytoplankton blooms often triggered by an upwelling regime. Therefore, seasonal upwelling cannot be excluded during deposition of the lower part of the section studied. However, as in other Carpathian Foredeep sections, a role of riverine input of nutrients is also expected from the occurrence of small oxyphilic opportunistic Cibicidoides spp., however, Epistominella and Cassidulina as markers of terrigenous input are missing.

3. The section studied can be subdivided into six intervals indicating the cyclical character of the Middle Miocene sedimentation in the Central Paratethys, triggered probably by Milanković climatic cyclicity. Cycles started with rapid warming and continued with gradual cooling. A seasonal succession of assemblages was interpreted mainly from co-occurrence of planktonic foraminifera species which characterized different seasons: a season with colder mixed water was followed by a season with stratification of the water column with an oligotrophic and warm upper layer and low oxic conditions at the sea-floor.
4. Interannual oscillations of nutrient content, temperature and/or salinity are inferred from oscillations of Th, $\mathrm{U}$ and $\mathrm{K}$ values and abundances of high-nutrient/oligotrophic-markers, warm/cold-water and stress markers.

5. Turnover of species correlated with the onset of the Middle Miocene Climatic Transition is recorded above the LO of Helicosphaera waltrans in agreement with previous observations in the Carpathian Foredeep. The changes include cooling, decrease of nutrients, probable increase of salinity of superficial water and increase in seasonality. Cooling is indicated by high numbers of otoliths of the cryophilic $G$. argenteus argenteus.

6 . A shallowing trend was recorded at the top of section.

Acknowledgements. The study was supported by the projects PRVOUK P44, CETPo CZ 1.07/2.3.00/20.0166 and IGA PdF_2015_029. The constructive reviews of $K$. Báldi, M. Oszczypko, D. Peryt and A. Wysocka substantially improved the manuscript. The authors greatly appreciate the work of the editor T. Peryt on the final form of the manuscript. We would like to thank P. Hudec for the kind introduction to the locality.

\section{REFERENCES}

Abdul Aziz, H.A., Di Stefano, L.M., Foresi, F.J., Hilgen, S.M., laccarino, K.F., Kuiper, F., Lirer, G., Salvatorini, A., Turco, E., 2008. Integrated stratigraphy and ${ }^{40} \mathrm{Ar} /{ }^{39} \mathrm{Ar}$ chronology of early Middle Miocene sediments from DSDP Leg 42A, Site 372 (Western Mediterranean). Palaeogeography, Palaeoclimatology, Palaeoecology, 257: 123-138.

Abu-Zied, R.H., Rohling, E.L., Jorissen, F.J., Fontanier, C., Casford, J.S.L., Cooke, S., 2008. Benthic foraminiferal response to changes in bottom-water oxygenation and organic carbon flux in the eastern Mediterranean during LGM to recent times. Marine Micropaleontology, 67: 46-68.

Bartol, M., 2009. Middle Miocene calcareous nannoplankton of NE Slovenia (western Central Paratethys). Založba ZRC/ZRC Publishing, Ljubljana.

Bé, A.W.H., 1977. An ecological, zoogeographic and taxonomic review of Recent planktonic foraminifera. In: Oceanic Micropaleontology. (ed. A.T.S. Ramsey): 1-100. Academic Press, London.

Berggren, W.A., Kent, D.V., Swisher, C.C. III, Aubry., M.-P., 1995. A revised Cenozoic geochronology and chronostratigraphy. SEPM Special Publication, 54: 129-212.

Berstad, S., Dypvik, H., 1982. Sedimentological evolution and natural radioactivity of Tertiary sediments from the central North Sea. Journal of Petroleum Geology, 5: 77-88.

Bijma, J., Faber, W.W.J., Hemleben, C., 1990. Temperature and salinity limits for growth and survival of some planktonic foraminifers in laboratory cultures. Journal of Foraminiferal Research, 20: 95-116.

Boeckel, B., Baumann, K.-H., Henrich, R., Kinkel, K., 2006 Coccolith distribution patterns in South Atlantic and Southern Ocean surface sediments in relation to environmental gradients. Deep-Sea Research I, 53: 1073-1099.

Brzobohatý, R., 1975. Otolitová fauna moravské předhlubně (in Czech). Manuscript, Dílčí zpráva Státního úkolu č. II-8 - 1/9. Univerzita Jana Evangelisty Purkyně Brno.

Brzobohatý, R., 1997. Paleobathymetry of the Lower Badenian (Middle Miocene, Carpathian Foredeep, South Moravia) based on otoliths. In: Dynamika vztahů marinního a kontinentálního prostředí (ed. Š. Hladilová): 37-45. Masarykova univerzita, Brno.
Brzobohatý, R., 2001. Paleogeography, paleobiogeography and bathymetry based on fish, particularly otoliths. Berichte des Institutes für Geologie and Paläontologie der Karl-Franzens-Universität Graz, Österreich, 4: 37-40.

Brzobohatý, R., Cicha, I., 1993. Karpatská předhlubeň (in Czech). In: Geology of Moravia and Silezia (eds. A. Přichystal, V. Obstová and M. Suk): 123-128. Moravské Zemské Muzeum, Brno.

Brzobohatý, R., Nolf, D., Kroupa, O., 2007. Fish otoliths from the Middle Miocene of Kienberg at Mikulov, Czech Republic, Vienna Basin: their paleoenvironmental and paleogeographic significance. Bulletin de l'Institut royal des Sciences naturelles de Belgique, Sciences de la Terre, 77: 167-196.

Cachao, M., Moita, M.T., 2000. Coccolithus pelagicus, a productivity proxy related to moderate fronts off Western Iberia. Marine Micropaleontology, 39: 131-155.

Caralp, M.H., 1989. Abundance of Bulimina exilis and Melonis barleeanum: relationship to the quality of marine organic matter. Geo-Marine Letters, 9: 37-43.

Caulle, C., Koho, K.A., Mojtahid, M., Reichart, G.J., Jorissen, F.J., 2014. Live (Rose Bengal stained) foraminiferal faunas from the northern Arabian Sea: faunal succession within and below the OMZ. Biogeosciences, 11: 1155-1175.

Chapman, M.R., 2010. Seasonal production patterns of planktonic foraminifera in the NE Atlantic Ocean: implications for paleotemperature and hydrographic reconstructions. Paleoceanography, 25, PA1101, doi:10.1029/2008PA001708

Conan, S.M.-H., Evanova, E.M., Brummer, G.-J.A., 2002. Quantifying carbonate dissolution and calibration of foraminiferal dissolution indices in the Somali Basin. Marine Geology, 182: 325-349.

DeCelles, P.G., Giles, K.A., 1996. Foreland basin systems. Basin Research, 8: 105-123.

Di Stefano, A., Foresi, L.M., Lirer, F., laccarino, S.M., Turco, E., Amore, F.O., Morabito, S., Salvatorini, G., Mazzei, R., Abdul Aziz, H., 2008. Calcareous plankton high resolution bio-magnetostratigraphy for the Langhian of the Mediterranean area. Rivista Italiana di Paleontologia e Stratigrafia, 114: 51-76.

Doláková, N., Brzobohatý, R., Hladilová, Š., Nehyba, S., 2008. The red algal facies of the Lower Badenian limestones of the 
Carpathian Foredeep in Moravia (Czech Republic). Geologica Carpathica, 59: 133-146.

Doláková, N., Holcová, K., Nehyba, S., Hladilová, Š., Brzobohatý, R., Zágoršek, K., Hrabovský, J., Seko, M., Utescher, T., 2014. The Badenian parastratotype at Židlochovice from the perspective of the multiproxy study. Neues Jahrbuch für Geologie und Paläontologie Abhandlungen, 271: 169-201.

Drinia, H., Antonarakou, A., Kontakiotis, G., Tsaparas, N., Segou, M., Karakitsios, V., 2007. Palaeobathymetric evolution of the Early Late Miocene deposits of the Pre-Apulian Zone, Levkas Island, Ionian Sea. Bulletin of the Geological Society of Greece, 40: 39-52

Dumon, J.C., Grousset, F., 1977. Variations verticales de certains constituants et paramètres organiques dans deux colonnes sédimentaires d'âge Riss à Actuel (Golfe de Gascogne). Essai d'interprétation. Bulletin Société Géologique de France, Paris, s. 7, 19: 177-182.

Flores, J.A., Sierro, F.S., Francés, G., Vasquez, A., Zamarreno, I., 1997. The last 100,000 years in the western Mediterranean: sea surface water and frontal dynamics as revealed by coccolithophores. Marine Micropaleontology, 29: 351-366.

Fontanier, C., Jorissen, F.J., Licari, L., Alexandre, A., Anschutz, P., Carbonel, P., 2002. Live benthic foraminiferal faunas from the Bay of Biscay: faunal density, composition, and microhabitats. Deep-Sea Research I, 49: 751-785.

Girone, A., Varola, A., 2001. Fish otoliths from the Middle Pleistocene deposits of Montalbano Jonico (Southern Italy). Bolletino della Societá Paleontologica Italiana, 40: 431-443.

Gooday, A.J., 1993. Deep-sea benthic foraminiferal species which exploit phytodetritus: characteristic features and controls on distribution. Marine Micropaleontology, 22: 187-205.

Gradstein, F.M., Ogg, J.G., Schmitz, M.D., Ogg, G.M., 2012. The Geologic Time Scale 2012 2-Volume Set. Elsevier, New York.

Hammer, Ø., Harper, D.A.T., Ryan, P.D., 2001. PAST: Paleontological Statistics Software Package for Education and Data Analysis. Palaeontologica Electronica, 4: 1-9.

Hamršmíd, B., 1985. Helicotaphrichnus commensalis z lokality Lomnice u Tišnova (in Czech). Manuscript, Dílčí zpráva Státního úkolu VI-1-13/01. Univerzita Jana Evangelisty Purkyně Brno: 176-188.

Haq, B.U., Hardenbol, J., Vail, P.R., 1988. Mesozoic and Cenozoic chronostratigraphy and eustatic cycles. SEPM Special Publication, 42: 71-108.

Harzhauser, M., Piller, W.E., Müllegger, S., Grunert, P., Micheels, A., 2011. Changing seasonality patterns in Central Europe from Miocene Climate Optimum to Miocene Climate Transition deduced from the Crassostrea isotope archive. Global and Planetary Change, 76: 77-84.

Hayek, L.C., Wilson, B., 2013. Quantifying assemblage turnover and species contributions at ecologic boundaries. PLoS ONE 8:e74999, http://dx.doi.org/10.1371/journal.pone.0074999

Hemleben, C., Spindler, M., Anderson, O.R., 1989. Modern Planktonic Foraminifera. Springer, New York.

Hermelin, J.O.R., 1992. Variations in the benthic foraminiferal fauna of the Arabian Sea: a response to changes in upwelling intensity? Geological Society London Special Publications, 64: $151-166$.

Hladil, J., 1976. Šestičetné koráli (Scleractinia) badenu (in Czech). Msc. thesis, Univerzita Jana Evangelisty Purkyně Brno.

Hladilová, Š., Nehyba, S., Doláková, N., Hladíková, J., 1999. Comparison of some relics of Miocene sediments on the eastern margin of the Bohemian Massif. Geologica Carpathica, 50: 31-33.

Hohenegger, J., 1995. Depth estimation by proportions of living larger foraminifera. Marine Micropaleontology, 26: 31-47.

Hohenegger, J., Andersen, N., Báldi, K., Ćorić, S., Pervesler, P., Rupp, C., Wagreich, M., 2008. Paleoenvironment of the Early Badenian (Middle Miocene) in the southern Vienna Basin (Austria) - multivariate analysis of the Baden-Sooss section. Geologica Carpathica, 59: 461-487.
Hohenegger, J., Ćorić, S., Wagreich, M., 2014. Timing of the regional Badenian Stage (Middle Miocene, Central Paratethys). Geologica Carpathica, 65: 55-66.

Holcová, K., 1999. Postmortem transport and resedimentation of foraminiferal tests: relations to cyclical changes of foraminiferal assemblages. Palaeogeography, Palaeoclimatology, Palaeoecology, 145: 157-182.

Holcová, K., Hrabovský, J., Nehyba, S., Hladilová, Š., Doláková, N., Demeny, A., 2015. The Langhian (Middle Badenian) carbonate production event in the Moravian part of the Carpathian Foredeep (Central Paratethys): a multiproxy record. Facies, 61: $1-26$.

Hudec, P., 1986. Sytematic and paleoecological analysis of molusca from Badenian locality Lomnice u Tišnova (in Czech). Msc. thesis, Prírodovědecká fakulta Masarykovy Univerzity Brno.

Hüsing, S.K., Cascella, A., Hilgen, F.J., Krijgsman, W., Kuiper, K.F., Turco, E., Winson, D., 2010. Astrochronology of the Mediterranean Langhian between 15.29 and $14.17 \mathrm{Ma}$. Earth and Planetary Science Letters, 290: 254-269.

Jahoda, V., 1988. Podrobná hydrogeologická studie okolí Lomnice u Tišnova (in Czech). Manuscript Archiv Geotest Brno.

Jorissen, F.J., Barmawidjaja, D.M., Puskaric, S., Van der Zwaan, G.J., 1992. Vertical distribution of benthic Foraminifera in the Northern Adriatic Sea. The relation with high organic flux. Marine Micropaleontology, 19: 131-146.

Jorissen, F.J., Destinger, H.C., Widmark, J.G.V., 1995. A conceptual model explaining benthic foraminifera microhabitat. Marine Micropaleontology, 26: 3-15.

Jorissen, F.J., Wittling, I., Peypouquet, J.P., Rabouille, C., Relexans, J.C., 1998. Live benthic foraminiferal faunas off Cap Blanc, NW Africa: community structure and microhabitats. Deep-Sea Research I, 45: 2157-2188.

Kaiho, K., 1994. Benthic foraminiferal dissolved-oxygen index and dissolved oxygen levels in the modern ocean. Geology, 22: 719-722.

Kameo, K., 2002. Late Pliocene Caribbean surface water dynamics and climatic changes based on calcareous nannofossil records. Palaeogeography, Palaeoclimatology, Palaeoecology, 179: 211-226.

Knappertsbusch, M., 1993. Geographic distribution of living and Holocene coccolithophores in the Mediterranean Sea. Marine Micropaleontology, 21: 219-247.

Kopecká, J., 2012. Foraminifera as environmental proxies of the Middle Miocene (Early Badenian) sediments of the Central Depression (Central Paratethys, Moravian part of the Carpathian Foredeep). Bulletin of Geosciences, 87: 431-442.

Kováč, M., 2000. Geodynamický, paleogeografický a štruktúrny vývoj Karpatsko-Panónskeho regiónu v miocéne: Nový pohl'ad na neogénne panvy Slovenska (in Slovak). Veda, Bratislava.

Kuhnt, T., Howa, H., Schmidt, S., Marié, L., Schiebel, R., 2013. Flux dynamics of planktic foraminiferal tests in the south-eastern Bay of Biscay (northeast Atlantic margin). Journal of Marine Systems, 109-110, Suppl.: S169-S181.

Leeuw, A., de, Bukowski, K., Krijgsman, W., Kuiper, K.F., 2010. The age of the Badenian Salinity Crisis; impact of Miocene climate variability on the Circum-Mediterranean region. Geology, 38: 715-718.

Longhurst, A.R., 2010. Ecological Geography of the Sea. Academic Press, San Diego.

Malmgren, B.A., Kennett, J.P., 1978. Late Quaternary paleoclimatic applications of mean size variations in Globigerina bulloides d'Orbigny in the Southern Indian Ocean. Journal of Paleontology, 52: 1195-1207.

Martini, E., 1971. Standard Tertiary and Quaternary Calcareous Nannoplankton Zonation. Proceedings of the II Planktonic Conference, Roma, 1970: 739-785. Tecnoscienza.

Miao, Q., Thunell, R.C., 1993. Recent deep-sea benthic foraminiferal distribution in the South China Sea. Marine Micropaleontology, 22: 1-32. 
Miller, K.G., Lohmann, G.P., 1982. Environmental distribution of recent benthic foraminifera on the northeast United States continental slope. GSA Bulletin, 93: 200-206.

Mísař, Z., Dudek, A., Havlena, V., Weiss, J., 1983. Geologie ČSSR I. - Český masiv.1-333 (in Czech). Státní pedagogické nakladatelství Praha.

Mojtahid, M., Griveaud, C., Fontanier, C., Anschutz, P., Jorissen, F. J., 2010. Live benthic foraminiferal faunas along a bathymetrical transect $(140-4800 \mathrm{~m})$ in the Bay of Biscay (NE Atlantic). Revue de Micropaléontologie, 53: 139-162.

Murray, J.W., 2003. Foraminiferal assemblage formation in depositional sinks on the continental shelf west of Scotland. Journal of Foraminiferal Research, 33: 101-121.

Murray, J.W., 2006. Ecology and Applications of Benthic Foraminifera. Cambridge University Press, Cambridge.

Nehyba, S., 1997. Miocene volcanoclastics of the Carpathian Foredeep in the Czech Republic. Věstník Českého geologického Ústavu, 72: 311-327.

Nehyba, S., Hladilová, Š., 2004. Relics of the most distal part of the Neogene foreland basin in SW Moravia. Bulletin of Geosciences, 79: 113-120.

Nehyba, S., Šikula, J., 2007. Depositional architecture, sequence stratigraphy and geodynamic development of the Carpathian Foredeep (Czech Republic). Geologica Carpathica, 58: 53-69.

Nehyba, S., Roetzel, R., Adamová, M., 1999. Tephrostratigraphy of the Neogene volcaniclastics (Moravia, Lower Austria, Poland). Geologica Carpathica, 50, Special Issue: 126-128.

Nehyba, S., Holcová, K., Gedl, P., Doláková, N., submitted: The Lower Badenian transgressive-regressive cycles - a case study from Oslavany (Carpathian Foredeep, Czech Republic). Neues Jahrbuch für Geologie und Paläontologie, Abhandlungen.

Nemec, W., 2005. Principles of lithostratigraphic logging and facies analyses. Institutt for Geovitenskap, Universitetet i Bergen.

Nolf, D., Brzobohatý, R., 1994. Fish otoliths as paleobathymetric indicators. Paleontologia i Evolucio, 24-25: 255-264.

Novák, Z., 1975. Spodnobádenské vápence karpatské předhlubně (in Czech). Ph.D. thesis, Univerzita Jana Evangelisty Purkyně Brno.

Okada, H., Mclntyre, A., 1979. Seasonal distribution of modern coccolithophores in the western North Atlantic Ocean. Marine Biology, 54: 319-328.

Oszczypko, N., 1998. The Western Carpathian Foredeep - development of the foreland basin in front of the accretionary wedge and its burial history (Poland). Geologica Carpathica, 49 415-431.

Oszczypko, N., Oszczypko-Clowes, M., 2012. Stages of development in the Polish Carpathian Foredeep Basin. Central European Journal of Geosciences, 4: 138-162.

Ozdínová, S., 2008. Badenian calcareous nannofossils from Semerovce ŠV - 8 and Cífer boreholes (Danube Basin). Mineralia Slovaca, 40: 135-140.

Papp, A., Cicha, I., Seneš, J., Steininger, F., 1978. M4 - Badenien (Moravien, Wielicien, Kosovien). Chronostratigraphie und Neostratotypen, Miozän der Zentralen Paratethys. 6. Veda, Bratislava.

Peryt, D., 1997. Calcareous nannoplankton stratigraphy of the Middle Miocene in the Gliwice area (Upper Silesia, Poland). Bulletin of the Polish Academy of Sciences, Earth Sciences, 45: 119-131.

Peryt, D., 2013. Foraminiferal record of the Middle Miocene climate transition prior to the Badenian salinity crisis in the Polish Carpathian Foredeep Basin (Central Paratethys). Geological Quarterly, 57 (1): 141-164

Plint, A.G., 2014. Mud dispersal across a Cretaceous prodelta: Strom-generated, wave-enhanced sediment gravity flows inferred from mudstone microtexture and microfacies. Sedimentology, 61: 609-647.

Pluskal, F.S., 1853. Die tertiäre Bucht bei Lomnitz. Mitgliede des Wernervereins zur geognostischen Durchforschung von Mähren und Schlesien.
Poore, R.Z., Tedesco, K.A., Spear, J.W., 2013. Seasonal flux and assemblage composition of planktic foraminifers from a sediment-trap study in the northern Gulf of Mexico. Journal of Coastal Research, Special Issue, 63: 6-19.

Procházka, V.J., 1892a. Předběžná zpráva o stratigrafických a faunistických poměrech nejzazší části miocenu západní Moravy (in Czech). Věstník královské české společnosti nauk: 326-368.

Procházka, V.J., 1892b. Miocaen moravský. První příspěvek ku poznání rázu zvířeny mořských jílů a slínů severo- západo a středomoravské oblasti. Věstník královské české společnosti nauk: 458-471.

Procházka, V.J., 1893. Geologický nástin Tišnovska (in Czech). V průvodci výstavy okresní v Tišnově, Tišnov: 19-50.

Procházka, V.J., 1899. Miocénové ostrovy v krasu Moravském (in Czech). Rozpravy České Akademie, 2: 1-37.

Radwańska, U., 1992. Fish otoliths in the Middle Miocene (Badenian) deposits of southern Poland. Acta Geologica Polonica, 42: 141-328.

Rathburn, A.E., Corliss, B.H., 1994. The ecology of deep-sea benthic foraminifera from the Sulu Sea. Paleoceanography 9: 87-150.

Reynolds, L., Thunell, R.C., 1985. Seasonal succession of planktonic foraminifera in the subpolar North Pacific. Journal of Foraminiferal Research, 15: 282-301.

Rider, M.H., 1999. The Geological Interpretation of Well Logs. Whittles Publication Services, Dunbeath.

Rigual-Hernández, A.S., Sierro, F.J., Bárcena, M.A., Flores, J.A., Heussner, S., 2012. Seasonal and interannual changes of planktic foraminiferal fluxes in the Gulf of Lions (NW Mediterranean) and their implications for paleoceanographic studies: two 12-year sediment trap records. Deep-Sea Research I: Oceanographical Research Papers, 66: 26-40.

Rohling, E.J., Jorissen, F.J., Vergnaud-Grazzini, C., Zachariasse, W.J., 1993. Northern Levantine and Adriatic Quaternary planktic foraminifera; reconstruction of paleoenvironmental gradients. Marine Micropaleontology, 21: 191-218.

Salmon, K.H., Anand, P., Sexton, P.F., Conte, M., 2014. Upper ocean mixing controls the seasonality of planktonic foraminifer fluxes and associated strength of the carbonate pump in the oligotrophic North Atlantic. Biogeosciences Discussion, 11: 12223-12254.

Schiebel, R., Hemleben, C., 2005. Modern planktic foraminifera. Paläontologische Zeitschrift, 79: 135-148.

Schiebel, R., Bijma, J., Hemleben, C., 1997. Population dynamics of the planktic foraminifer Globigerina bulloides from the eastern North Atlantic. Deep Sea Research Part I: Oceanographic Research Papers, 44 (9-10): 1701-1713.

Schmidt, M.W., Spero, H.J., Lea, D.W., 2004. Links between salinity variation in the Caribbean and North Atlantic thermohaline circulation. Nature, 428: 160-163.

Schmuker, B., 2000. Recent Planktonic Foraminifera in the Caribbean Sea: Distribution, Ecology and Taphonomy, Ph.D. thesis, ETH, Zurich.

Schönfeld, J., 2001. Benthic foraminifera and pore-water oxygen profiles: a re-assessment of species boundary conditions at the western Iberian margin. Journal of Foraminiferal Research, 31: 86-107.

Selmeczi, I., Lantos, M., BohnHavas, M., Nagymarosy, A., Szegö, E., 2012. Correlation of bio- and magnetostratigraphy of Badenian sequences from western and northern Hungary. Geologica Carpathica, 63: 219-232.

Sen Gupta, B.K., Machain-Castillo, M.L., 1993. Benthic foraminifera in oxygen-poor habitats. Marine Micropaleontology, 20: 183-201.

Sjoerdsma, P.G., Van der Zwaan, G.J., 1992. Simulating the effect of changing organic flux and oxygen content on the distribution of benthic foraminifera. Marine Micropaleontology, 19: 163-180.

Švábenická, L., 2002. Calcareous nannofossils of the Upper Karpatian and Lower Badenian deposits in the Carpathian 
Foredeep, Moravia (Czech Republic). Geologica Carpathica, 53: 197-210.

Thomas, E., Booth, L., Maslin, L., Shackleton., N.J., 1995. Northeastern Atlantic benthic foraminifera during the last 45.000 years: productivity changes as seen from the bottom up. Paleoceanography, 10: 545-562.

Tucker, M.E., 1995. Sedimentary Rocks in the Field. J. Wiley \& Sons, Chichester.

Van der Zwaan, G.J., Jorissen, F.J., De Stiger, H.C., 1990. The depth dependency of planktonic/benthonic foraminiferal ratios: constraints and applications. Marine Geology, 95: 1-16.

Van Morkhoven, F.P.C.M., Berggren, W.A., Edwards, A.S., 1986. Cenozoic cosmopolitan deep-water benthic foraminifera. Bulletin des Centres de Recherches Exploration-Production Elf-Aquitaine, Memoires, 11: 1-421.

Wade, B.S., Bown, P.R., 2006. Calcareous nannofossils in extreme environments: the Messinian Salinity Crisis, Polemi Basin, Cyprus. Palaeogeography, Palaeoclimatology, Palaeoecology, 233: 271-286.

Walker, R.G., James, N.P., 1992. Facies Models. Response to Sea Level Changes. Geological Association of Canada, Toronto.

Wells, P., Okada, H., 1997. Response of nannoplankton to major changes in seasurface temperatrure and movements of hydro- logical fronts over site DSDP 594 (south Chatham Rise, southeastern New Zealand), during the last 130 kyr. Marine Micropalaeontology, 32: 341-363.

Winter, A., Jordan, R.W., Roth, P.H., 1994. Biogeography of the living coccolithophores in the oceans. In: Coccolithophores (eds. A. Winter and W. Siesser): 161-178. Cambridge University Press, Cambridge.

Zágoršek, K., Holcová, K., Nehyba, S., Kroh, A., Hladilová, Š. 2009. The invertebrate fauna of the Middle Miocene (Lower Badenian) sediments of Kralice nad Oslavou (Central Paratethys, Moravian part of the Carpathian Foredeep). Bulletin of Geosciences, 84: 465-496.

Zdražílková, N., 1985. Řasové vápence badenu karpatské předhlubně (in Czech). Msc. thesis, Univerzita Jana Evangelisty Purkyně Brno.

Ziveri, P., Thunell, R.C., Rio, D., 1995. Export production of coccolithophores in an upwelling region: results from San-Pedro Basin, Southern California Borderlands, Marine Micropaleontology, 24: 335-358.

Ziveri, P., Baumann, K.-H., Böckel, B., Bollmann, J., Young, J., 2004. Biogeography of selected Holocene coccoliths in the Atlantic Ocean. In: Coccolithophores from molecular processes to global impact. (eds. H.R. Thierstein and J.R. Young): 403-428. Springer, Berlin. 